[RaplocarboN, Vol. 11, No. 2, 1969, P. 351-390]

\title{
GRONINGEN RADIOCARBON DATES VIII
}

\author{
J. C. VOGEL and J. C. LERMAN* \\ University of Groningen \\ Physics Laboratory, Westersingel 34, Groningen, Netherlands
}

\section{INTRODUCTION}

This list contains dates for Latin America which have mainly been measured during the past few years. The results are grouped into three categories: geologic, archaeologic, and geophysical, and arranged according to the country of provenance, passing roughly from $\mathrm{N}$ to $\mathrm{S}$. Most of the geologic samples are connected with palynologic studies. In cases where the influence of man is apparent in the pollen diagrams, this is explicitly mentioned. Descriptions and comments are based on information provided by the collectors or submitters and on the publications referred to under each sample or series. For the archaeologic section reference has also been made to the general works of Meggers and Evans (1963), Jennings and Norbeck (1964), and Willey (1966).

Unless otherwise stated, the samples were treated before combustion, in the usual manner with dilute acid, alkali, and acid, respectively. Collagen from bone has been obtained by prolonged pretreatment with very dilute hydrochloric acid. The results are expressed in terms of the conventional $\mathrm{C}^{14}$ scale as defined in the Editorial Statement of Radiocarbon (w.r.t. NBS standard; $\mathrm{t}_{1 / 2}=5568 \mathrm{yr}$; reference year A.D. $1950=$ 0 B.P.).

The $\mathrm{C}^{13} / \mathrm{C}^{12}$ ratio of most of the samples has been measured under the supervision of W. G. Mook. The dates which include $\delta \mathrm{C}^{13}$ values (all given relative to the PDB standard) have been corrected for deviations from the "normal" value of $\delta \mathrm{C}^{13}=-25.0 \%$ unless otherwise mentioned. Especially large additive corrections of as much as 240 years are necessary in the case of maize ( $\mathrm{GrN}-4729$ and $\mathrm{GrN}-5396)$ since the deviating $\mathrm{C}^{13}$ / $\mathrm{C}^{12}$ ratio must be ascribed to physiological rather than ecological reasons. This has been mentioned implicitly by Münnich and Vogel (1958) and Münnich (1961). Not only maize and some other tropical grasses (teosinte and Tripsacum) show this characteristic but also succulent xerophytes (pineapple, Agave, Bryophyllum, and Kalanchö̈) (J. C. Lerman and A. S. Talma, unpubl. measurements). Several plants of these groups grow in the Americas and have been used as food and for building, matting, clothing, etc. Thus, some dates may appear too young if $\delta \mathrm{C}^{13}$ is not measured. Bone samples from the dry South American tablelands show a greater enrichment in $\mathrm{C}^{13}$ than do European bones, presumably because of $\mathrm{C}^{13}$ enriched plants in the diet of animals and man. Some samples (GrN-5399, GrN-5400, and GrN-5440) required corrections for isotope fractionation of ca. 170 years.

All dates younger than 550 B.P. have been corrected for secular variations in $\mathrm{C}^{14}$ by means of the correction curves of Stuiver and Suess

* Present address: University of Bern, Physics Laboratory, Sidlerstrasse 5, 3000 Bern, Switzerland. 
(1966) for the Northern Hemisphere and the Patagonian tree rings curve (J. C. Lerman et al., ms. in preparation) for the S Hemisphere. The derived historical dates for the interval $\pm 1 \sigma$ are given in the comments.

\section{ACKNOWLEDGMENTS}

Thanks are due to all who have assisted in measuring samples, especially to H. J. Streurman and Miss G. H. Pijpen $\left(\mathrm{C}^{14}\right)$ and Miss C. Sijbolts $\left(\mathrm{C}^{13}\right)$ who have performed the analyses during the past few years.

\section{GEOLOGIC SAMPLES}

\section{A. Cuba}

\section{Ciénaga de Zapata series, Las Villas, Cuba}

Three secs. taken with sonde at Ciénaga de Zapata peat marsh in Península de Zapata (ca. $22^{\circ} 11^{\prime} \mathrm{N}$ Lat, $80^{\circ} 47^{\prime} \mathrm{W}$ Long), W of Bahía de Cochinos, along S coast, prov. of Las Villas, Cuba. Samples belong to same level as Jamaica sample (see below) and should indicate beginning of peat growth. Present sea level is ca. $2 \mathrm{~m}$ below ground level. Pollen analyses of secs. (R. A. Couper, written commun., 1959) indicate that mangrove swamps were not extensive in region and that no great change occurred in time. Chenopodiaceae do not grow nowadays in the area but their pollen is present in cores. Coll. 1959 and subm. by W. H. van der Molen, Grontmij, De Bilt, Netherlands.

\section{GrN-2098. Ciénaga de Zapata D9}

$5130 \pm 90$

Peat from ca. $4 \mathrm{~m}$ depth at D9/Final Zanja Alzagaray. Underlying sediments are limestone. Overlying layer has abundant Chenopodiaceae pollen $(55 \%)$ indicating that site was closer to sea level or that water was somewhat more brackish than at present.

\section{GrN-2099. Ciénaga de Zapata D40}

$5400 \pm 80$

Peat from 3.50 to $3.75 \mathrm{~m}$ depth at $\mathrm{D} 40 / \mathrm{EB} 8$, ca. $18 \mathrm{~km}$ SE of site D9. Underlying sediments are clay and limestone.

GrN-2089. Ciénaga de Zapata D50 $5320 \pm 90$ 3370 в.c.

Peat from 3.50 to $4.00 \mathrm{~m}$ depth, at $\mathrm{D} 50 / \mathrm{BB} 11$, near Hatiguanico R., ca. $40 \mathrm{~km} \mathrm{NNW}$ of D9. Underlying sediments consist of limestone. General Comment: dates correlate with 3 dates of peat in Florida, U.S.A., L-141A: $4900 \pm 200$; L-141B: $3800 \pm 200$, L-141C: $5050 \pm 200$ (Science, 1952 , v. 116, p. 411) and agree with geologic assumption that peat was formed during last transgression (C. Voûte, written commun., 1959). Only acid pretreatment.

\section{B. Jamaica}

\section{GrN-4599. Jamaica 11 BM VII, Jamaica}

$6010 \pm 60$

4060 B.C.

$\delta C^{13}=-27.7 \%$

Peat from 650 to $680 \mathrm{~cm}$ depth $(6 \mathrm{~m}$ below present sea level) in 
boring at Lower Morass, Black R. (ca. $18^{\circ} 0^{\prime} \mathrm{N}$ Lat, $77^{\circ} 38^{\prime} \mathrm{W}$ Long), Jamaica. From bottom part of saw-grass peat formation resting on Miocene Limestone, dates beginning of peat growth and rise of sea above this level. Coll. 1964 and subm. by W. H. van der Molen. Comment: result confirms expectations and correlates with similar determinations in Ciénaga de Zapata, Cuba (see above).

\section{Colombia}

\section{Sierra Nevada de Santa Marta series, Magdalena, Colombia}

Secs. of lake sediments from Valley of Donachui R. $\left(10^{\circ} 55^{\prime} \mathrm{N}\right.$ Lat, $73^{\circ} 40^{\prime} \mathrm{W}$ Long) in Sierra Nevada de Santa Marta, dept. of Magdalena, Colombia. This high coastal mountain range reaches nearly $5800 \mathrm{~m}$ alt at $50 \mathrm{~km}$ from coast. Snow limit is at ca. $5000 \mathrm{~m}$. Cores were taken in valley leading to pass between peaks Bolívar and Ojeda-Reina. Pollen analyses and interpretation by Lucas-Rappard (in preparation). Primary interest was to date moraines of 2 different glaciers, one from Pico de la Reina (secs. SN-I and SN-II) and another from Pico Tairona-Guardian $(\mathrm{SN}-\mathrm{V})$. Three stadia of glaciation are known for this region (Raasveldt, 1957): Estado Bolivariano, Gran Estado Mamancanacá, and Estado Aduriameina. Coll. 1958 and subm. by T. van der Hammen, Hugo de Vries Lab., Univ. of Amsterdam, Netherlands.

\section{GrN-4356. Sierra Nevada de Santa Marta,} Col. 40

$$
\begin{aligned}
& 170 \pm 65 \\
& \text { A.D. } 1780 \\
& \delta C^{13}=-25.2 \%
\end{aligned}
$$

Sandy peat from Sec. SN-1, at 60 to $76 \mathrm{~cm}$ depth. Core SN-I was taken at $4760 \mathrm{~m}$ alt and is $100 \mathrm{~cm}$ long. Comment: from known secular variations in $\mathrm{C}^{14}$, estimated historical date (see Introduction) is between A.D. 1640 and A.D. 1840.

GrN-4388. Sierra Nevada de Santa Marta, Col. 41

$280 \pm 65$ A.D. 1670 $\delta C^{13}=-24.7 \%$

Clay with plant remains, from Sec. SN-II, at 70 to $90 \mathrm{~cm}$ depth. Ciore SN-II was taken at $4700 \mathrm{~m}$ alt and is $120 \mathrm{~cm}$ long. Comment: estimated historical date is between A.D. 1490 and A.D. 1640 .

GrN-4357. Sierra Nevada de Santa Marta, Col. 42

$$
\begin{aligned}
& 1320 \pm 70 \\
& \text { A.D. } 630 \\
& \delta C^{13}=-23.7 \% c
\end{aligned}
$$

Clay with plant remains from Sec. SN-V, at 94 to $101 \mathrm{~cm}$ depth. Ciore SN-V, $120 \mathrm{~cm}$ long, was taken at $4420 \mathrm{~m}$ alt in valley of Catacá $\mathrm{R}$.

GrN-4358. Sierra Nevada de Santa Marta, Col. 43 a

$8485 \pm 70$ 6535 B.C. $\delta C^{13}=-26.9 \% / c$

Clay with plant remains, from Sec. SN-VII, at 115 to $120 \mathrm{~cm}$ depth. Sec. SN-VII, $160 \mathrm{~cm}$ long, is from eroded peat bog overlying moraine, near base camp in Naboba, $4480 \mathrm{~m}$ alt. 
GrN-4359. Sierra Nevada de Santa Marta, Col. 44b

Clay with plant remains, from Sec. SN-VII, at 101 to $108 \mathrm{~cm}$ depth.

GrN-4389. Sierra Nevada de Santa Marta, Col. 45
$3550 \pm 60$ 1600 B.c.

$\delta C^{13}=-22.0 \%$

Peat, from Sec. SN-IX, between 210 and $230 \mathrm{~cm}$ depth. Core SN-IX, $400 \mathrm{~cm}$ long, is from small lake at basis camp in Naboba.

General Comment: Secs. SN-I and SN-II date Estado Bolivariano moraines. From $\mathrm{C}^{14}$ dates it is estimated that end moraine where SN-I was taken, must have been emplaced prior to A.D. 1710. At locality SN-II upper end moraine originated after A.D. 1650, and lower end moraine dates before A.D. 1700. Beginning of sedimentation of $\mathrm{SN}-\mathrm{V}$ is estimated at A.D. 370. On basis of dates for SN-VII pollen diagrams can be correlated with European vegetational development and suggest that local end moraine originated during European Younger Dryas. This moraine lies between moraines of Bolívar and Mamancanacá stadia.

\section{Lower Magdalena Valley series, Bolívar, Colombia}

Sec. in Ciénaga de Morrocayal ( $8^{\circ} 40^{\prime} \mathrm{N}$ Lat, $74^{\circ} 15^{\prime} \mathrm{W}$ Long), W of El Banco, dept. of Bolívar, Colombia. Ciénaga del Morrocayal is shallow lake in lower course of Magdlalena R., caused by depressions of old river beds and partly filled with sediments deposited by Magdalena R. Locality situated at ca. $+20 \mathrm{~m}$. Sec. more than $7 \mathrm{~m}$ deep was taken with sonde. Pollen diagram interpreted and discussed by Wijmstra (1967). Samples taken in peat layers between 350 to $410 \mathrm{~cm}$ depth. Coll. 1956 and subm. by $\mathrm{T}$. van der Hammen.

GrN-2425. Lower Magdalena Valley, Col. 18a A.D. 1470

$480 \pm 60$

Humic clay with charcoal particles from 350 to $370 \mathrm{~cm}$ depth. Pollen Zone E. Comment: historical date, derived from calibration of $\mathrm{C}^{14}$ scale with tree rings (see Introduction), is A.D. 1400 to A.D. 1450.

GrN-2427. Lower Magdalena Valley, Col. 18b A.D. 1230

$720 \pm 80$

Humic clay from 390 to $410 \mathrm{~cm}$ depth corresponding to upper part of Pollen Zone D.

General Comment: 1st pollen diagram from tropical Magdalena Valley. It shows climatic sequences of humid and dry stages. From $\mathrm{C}^{14}$ analyses 2 periods of low water table apparent in upper parts of Pollen Zones $\mathrm{D}$ and $\mathrm{E}$ are dated between A.D. 1100 and A.D. 1500. These periods appear synchronous with similar events in Colombia (see Laguna de la Herrera series, this list). Sedimentation lasted ca. 750 yr (Wijmstra, 1967). Only acid pretreatment. 
Valle de Lagunillas series, Boyacá, Colombia

Three secs. at Valle de Lagunillas (ca. $6^{\circ} 30^{\prime} \mathrm{N}$ Lat, $72^{\circ} 30^{\prime} \mathrm{W}$ Long), Andean valley at $3880 \mathrm{~m}$ alt (S segment of Quebrada de la Cueva), along W base of Sierra Nevada del Cocuy, highest part of Cordillera Oriental, dept. of Boyacá, Colombia.

Valley contains series of lakes. Its slope, sufficiently small, has not favored excessive erosion of glacial drifts and is thus suitable for Quaternary investigations (González et al., 1965). Secs. of lake sediments related to glacial drifts were taken at 3 sites in $\mathrm{N}$ part of Valle de Lagunillas. Coll. 1959 and subm. by T. van der Hammen.

GrN-3504. Valle de Lagunillas, Col. 56

$6510 \pm 85$ 4560 в.c.

Peat from Core VL-VIII at 112 to $125 \mathrm{~cm}$ depth. Colombian Pollen Zone VI. Core, from small dissected basin between 2 end moraines of Drift II, is $170 \mathrm{~cm}$ long and shows thin layers of clay and sand alternating with peat and gravel. Comment: only acid pretreatment.

GrN-3112. Valle de Lagunillas, Col. 57

$9830 \pm 90$ Zone IV. Comment: only acid pretreatment.

GrN-3598. Valle de Lagunillas, Col. 53

$8190 \pm 100$ 6240 B.c.

GrN-4003. Valle de Lagunillas, Col. 53

$8200 \pm 100$

Peat from Cut VL-V, at 198 to $206 \mathrm{~cm}$ depth. Colombian Pollen Zones V and VI. Analyses consist of different portions of same sample. Cut VL-V from lake sediments in exposed sequence $806 \mathrm{~cm}$ long, $\mathrm{N}$ of IV boundary of Drift III. Peat is intercalated with clay, sand, and gravel. Below $620 \mathrm{~cm}$ periodic alternations of sand and clay suggest varves.

GrN-4141. Valle de Lagunillas, Col. 52

$10,030 \pm 90$ 8080 B.c. $\delta C^{13}=-27.2 \%$

Peat from Cut VL-V, at 232 to $252 \mathrm{~cm}$ depth. Colombian Pollen Zone IV.

GrN-4140. Valle de Lagunillas, Col. 51

$10,400 \pm 120$

8450 в.c.

Peat from Cut VL-V, at 275 to $300 \mathrm{~cm}$ depth. Colombian Pollen Zone III.

GrN-4083. Valle de Lagunillas, Col. 50

$11,350 \pm 140$

9400 в.c.

Peat from Cut VL-V, at 326 to $350 \mathrm{~cm}$ depth. Colombian Pollen Zone II. 
GrN-4036. Valle de Lagunillas, Col. 49 Zone Ic.

Peat from Cut VL-V, at 372 to $378 \mathrm{~cm}$ depth. Colombian Pollen

GrN-4002. Valle de Lagunillas, Col. 48

$12,140 \pm 120$

Peat from Cut VL-V, at 472 to $486 \mathrm{~cm}$ depth. Colombian Pollen Zone Ib.

GrN-4037. Valle de Lagunillas, Col. 47

$12,310 \pm 160$

10,360 в.c.

Wood from Cut VL-V, at 547 to $564 \mathrm{~cm}$ depth. Colombian Pollen Zone Ib.

GrN-3247. Valle de Lagunillas, Col. 46

$12,320 \pm 100$

10,370 в.C.

Peat from Cut VL-V, at 626 to $631 \mathrm{~cm}$ depth. Colombian Pollen Zone Ib.

GrN-4663. Valle de Lagunillas, Col. 55

$11,060 \pm 65$

Peat from cut at some hundred $\mathrm{m}$ downstream of VL-V on same terrace along Lagunillas R., at ca. 280 to $285 \mathrm{~cm}$ depth. Peat horizon was in $70 \mathrm{~cm}$ clay layer intercalated in $>630 \mathrm{~cm}$ sand, gravel, and clayish sands. Comment: date proves that considerable coarse material of fluvioglacial origin accumulated in valley immediately before European Aller $\phi \mathrm{d}$ and during Younger Dryas times. This date was not mentioned by González et al. (1965).

General Comment: dated pollen sequence provides information on paleoclimate and enables correlation of Colombian and $\mathrm{N}$ European zones. Dated drifts are approx. synchronous with North American drifts. It is concluded that general features of climate in high alt localities of tropical South America were synchronous with those of North America and Europe at mid- and high lats.

\section{Laguna de los Bobos series, Boyacá, Colombia}

Sec. of lake sediments at Laguna de los Bobos (del Bobo) $\left(6^{\circ} 20^{\prime}\right.$ $\mathrm{N}$ Lat, $72^{\circ} 50^{\prime} \mathrm{W}$ Long), at $3800 \mathrm{~m}$ alt in Páramo de Guantiva, Cordillera Oriental, dept. of Boyacá near boundary with Santander, Colombia. Described and interpreted by van der Hammen (1962), and van der Hammen and González (1965b).

Laguna de los Bobos is glacial cirque lake, on W slope of Alto de los Bobos, some $200 \mathrm{~m}$ below summit and draining over rock rim. Core $225 \mathrm{~cm}$ long was taken in shallow area ca. $20 \mathrm{~cm}$ deep, at $\mathrm{N}$ side of lake. Purpose of investigation was to gather information about past climate and flora. Presence of man is attested by pollen of maize in core. Coll. 1958 and subm. by T. van der Hammen. 
GrN-2422. Laguna de los Bobos, Col. 33

A.D. 1130

$820 \pm 60$

Clay gyttja with charcoal, from $62 \mathrm{~cm}$ to $78 \mathrm{~cm}$ below bottom of lake.

GrN-2430. Laguna de los Bobos, Col. 34

$1175 \pm 60$

Clay gyttja with charcoal, from $82 \mathrm{~cm}$ to $98 \mathrm{~cm}$ below bottom of lake.

GrN-2426. Laguna de los Bobos, Col. 35

$1990 \pm 60$

Clay gyttja, from $102 \mathrm{~cm}$ to $118 \mathrm{~cm}$ below bottom of lake.

\section{GrN-2429. Laguna de los Bobos, Col. 36}

$3095 \pm 95$

Clay gyttja from 122 to $138 \mathrm{~cm}$ below bottom of lake.

General Comment: samples belong to Colombian Pollen Zones VII and VIII which correspond to European Sub-Boreal and Sub-Atlantic zones. Calculated sedimentation rate is ca. $11 \mathrm{~cm} / 100 \mathrm{yr}$. Cultivation of maize occurs mainly between ca. 300 B.C. and A.D. 1200 . Only acid pretreatment.

\section{Ciénaga del Visitador series, Boyacá, Colombia}

Sec. from mountain mire Ciénaga del Visitador $\left(6^{\circ} 8^{\prime} \mathrm{N}\right.$ Lat, $72^{\circ}$ $47^{\prime} \mathrm{W}$ Long), at $3300 \mathrm{~m}$ alt, in rather dry plateau in Cordillera Oriental, Páramo del Desaguadero, Páramo de Guantiva, Susacá, dept. of Boyacá, Colombia.

Sec. taken with sonde exceeds $4 \mathrm{~m}$. Pollen diagram by van der Hammen and González (1965b). Coll. 1958 and subm. by T. van der Hammen.

\section{GrN-2477. Ciénaga del Visitador, Col. 32}

$9830 \pm 140$ 8880 в.c.

Dark lake sediment, from 270 to $300 \mathrm{~cm}$ depth. Cordilleran Pollen Zone Ia, upper part.

\section{GrN-3053. Ciénaga del Visitador, Col. 24}

$12,770 \pm 130$

11,820 в.C.

Dark lake sediment, from 370 to $390 \mathrm{~cm}$ depth. Cordilleran Pollen Zone IV.

General Comment: in contrast to Holocene section that of Lake Glacial shows low Gramineae contents, explained by assuming wetter local climate on plateau. Pollen boundaries deduced from calculated sedimentation rate of $3 \mathrm{~cm} / 100 \mathrm{yr}$ are closely synchronous with those in Europe (van der Hammen and González, 1965b). This diagram was tentatively correlated with strata at several early man sites in South America by Lanning and Patterson (1967). An interstadial earlier than $\mathrm{B} \not$ lling, Susacá interstadial, has been found between 13,700 to 13,100 B.P. (van der Hammen and Vogel, 1966). Only acid pretreatment. 


\section{$\mathbf{5 0 , 2 0 0}$ \\ GrN-4655. Tibitó, Col. 5, Cundinamarca, \\ 48,250 в.C. \\ Colombia}

Humic clay, from 260 to $280 \mathrm{~cm}$ depth, in lake sediments bored with sonde in Sabana de Bogotá near Tibitó (ca. $5^{\circ} \mathrm{N}$ Lat, $74^{\circ} \mathrm{W}$ Long), ca. alt $2580 \mathrm{~m}$, dept. of Cundinamarca, Colombia. Dates vegetational and climatic fluctuation with denser forests. Molar (Mastodon sp.) was found in fine sand layer at ca. 50 to $80 \mathrm{~cm}$ depth in same sec. Thus date gives terminus post quem for this extinct fauna. Coll. 1957 and subm. by T. van der Hammen. Comment: samples of Mondoñedo series (this list) give terminus ante quem (ca. 12,000 B.P.) for Mastodon-fauna (van der Hammen, 1966).

\section{Tenjo series, Cundinamarca, Colombia}

Sec. for pollen analyses from $\mathrm{N}$ part of Sabana de Bogotá (ca. $4^{\circ}$ $50^{\prime} \mathrm{N}$ Lat, $74^{\circ} 10^{\prime} \mathrm{W}$ Long), ca. $2580 \mathrm{~m}$ alt, near Tenjo, dept. of Cundinamarca, Colombia. Samples Col. 63b and Col. 64 are from exposure along road and should date important climatic change in stratum of dead trees and charcoal due to forest fires. Sample Col. 65 is from deeper level in borehole at same locality. Coll. 1966 and subm. by T. van der Hammen.

GrN-5017. Tenjo, Col. 63b

Wood from $320 \mathrm{~cm}$ depth, underlain by peaty clay.

$$
\delta C^{13}=-25.9 \% c
$$

\section{GrN-5018. Tenjo, Col. 64}

$39,200 \pm 1700$

Peaty clay with charcoal from same level as Col. 63b.

GrN-5019. Tenjo, Col. 65

Very compact peat from ca. $450 \mathrm{~cm}$ depth.

eneral Comment: other comparable dates are Sabana de Bogotá, GrN4417: $39,000 \pm 1000$ (this list), and La Candelaria, GrN-4657: 42,200 $+2600$

- 2000 (this list) which might correspond to same stratum as Col. 63b and Col. 64; and Tibitó, GrN-4655: 50,200 +5000 (see above) which could correspond to layer of Col. 65. Conclusion from dates is that $320 \mathrm{~cm}$ layer must be older than 39,000 B.P.

\section{GrN-4656. La Línea, Col. 17, Caldas-Tolima, $\quad 7980 \pm 80$ Colombia \\ 6030 B.C.}

Humic layer from 310 to $340 \mathrm{~cm}$ depth in exposure of volcanic ash at La Línea (ca. $4^{\circ} 30^{\prime} \mathrm{N}$ Lat, $75^{\circ} 30^{\prime} \mathrm{W}$ Long), in Central Cordillera, 
near highest point $(2760 \mathrm{~m}$ alt) of Ibaqué-Armenia Rd., on boundary depts. of Caldas and Tolima, Colombia. Coll. 1956 and subm. by T.van der Hammen. Comment: only acid pretreatment.

\section{GrN-5172. Quebrada Catarniquera, Col. 62, Tolima, $3780 \pm 95$ Colombia 1830 в.C.}

Scattered pieces of charcoal from natural exposure in canyon in Quebrada Catarniquera (ca. $4^{\circ} 13^{\prime} \mathrm{N}$ Lat, $75^{\circ} \mathrm{W}$ Long), at ca. $400 \mathrm{~m}$ alt, near Chicoral, dept. of Tolima, Colombia. Sample from layer in varved gray clay $8 \mathrm{~m}$ below surface of terrace. Nearby, at El Espinal, an arrowhead found in same terrace at approx. same depth in similar layer of clay was expected to give approx. date for industry (Robledo, 1955). Coll. 1966 and subm. by T. van der Hammen. Comment: date is surprisingly young for terrace-fan deposit of such extension and at ca. $30 \mathrm{~m}$ above river. Only acid pretreatment.

\section{Laguna de la Herrera series, Cundinamarca, Colombia}

Sec. in Laguna de la Herrera $\left(4^{\circ} 40^{\prime} \mathrm{N}\right.$ Lat, $74^{\circ} 20^{\prime} \mathrm{W}$ Long), at ca. $2550 \mathrm{~m}$ alt, on W border of Sabana de Bogotá, $5 \mathrm{~km} \mathrm{SW}$ of Mosquera, dept. of Cundinamarca, Colombia. Pollen analyses described and interpreted by van der Hammen and González (1965a).

Purpose of investigation was correlation of pollen zones with those of E Cordillera (Cordillera Oriental) and study of fluctuations in lake level. This is located in zone of rather dry climate with xerophytic vegetation. Characteristics of vegetation are described by van der Hammen and González (1960) and geology of region by van der Hammen and Parada (1958).

Length of core ca. $5 \mathrm{~m}$. Sediments consist mainly of diatom gyttja with layers of clay or peat. Base is greenish to white hard clay probably belonging to older eroded sediments which are exposed in nearby hills. Coll. 1957 and subm. by T. van der Hammen.

GrN-4297. Laguna de la Herrera, Col. 23

Clay with plant remains and charcoal, from 30 to $40 \mathrm{~cm}$ below bottom of lake. Pollen Zone VIII. Only acid pretreatment.

GrN-4123. Laguna de la Herrera, Col. 22 $\mathbf{7 0 0} \pm \mathbf{6 5}$
A.D. 1250
$\delta C^{13}=-27.0 \%$

Diatom gyttja with plant remains, from 57 to $72 \mathrm{~cm}$ below bottom of lake. Pollen Zone VIII.

GrN-4122. Laguna de la Herrera, Col. 21

$$
\begin{array}{r}
2050 \pm 50 \\
100 \text { B.c. } \\
\delta C^{13}=-29.2 \% \text {. }
\end{array}
$$

Diatom gyttja with plant remains, from 182 to $198 \mathrm{~cm}$ below bottom of lake. Pollen Zone VIII. 
GrN-4005. Laguna de la Herrera, Col. 20

Diatom gyttja with plant remains, from 405 to $417 \mathrm{~cm}$ below bottom of lake. Pollen Zone VII. Comment: only acid pretreatment.

GrN-3606. Laguna de la Herrera, Col. 19

$5020 \pm 80$

3070 B.c.

Diatom gyttja with plant remains, from 445 to $455 \mathrm{~cm}$ below bottom of lake. Pollen Zone VII.

General Comment: first 3 peaty layers dated correspond to low levels of lake and are synchronous with drier climatic periods in other regions of Colombia: Magdalena Valley, GrN-2427: $720 \pm 80$ and GrN-2425: $480 \pm 60$ (this list); Laguna de Agua Sucia GrN-4416: $2210 \pm 35$ (this list). Fourth peaty layer dated by Col. 19 and Col. 20 could represent either another dry period or beginning of inundation of area. It correlates with peat layer in Páramo de Palacio, W-781: $4740 \pm 160$ (Radiocarbon, 1960, v. 2, p. 179) and with beginning of European Sub-Boreal. Human influence on vegetation is observed after ca. 1200 B.P. and signs of burning in region occur at ca. 600 B.P. (Col. 23) (van der Hammen and González, 1965a). Compare GrN-4004: $1110 \pm 60$ for early Chibcha culture (this list).

\section{Mondoñedo series, Cundinamarca, Colombia}

Sec. from Upper Mondoñedo Formation in municipality of Mosquera $\left(4^{\circ} 40^{\prime} \mathrm{N}\right.$ Lat, $74^{\circ} 30^{\prime} \mathrm{W}$ Long), at ca. $2600 \mathrm{~m}$ alt, dept. of Cundinamarca, Colombia. Samples consist of fossil soil, abounding in charcoal and intercalated in sandy loam layers, exposed in deep erosion canyons at $4 \mathrm{~m}$ and $7 \mathrm{~m}$ depth respectively. The Mondoñedo Formation is on edges of Sabana de Bogotá, a former "pluvial" lake. Mastodon-fauna, in Lower Middle Mondoñedo Formation (see Tibitó, this list) was provisionally dated by fluorine analysis as Early Würm Glacial to Late Riss Würm Interglacial. Coll. 1962 and subm. by T. van der Hammen. Sec. and pollen diagram described by van der Hammen (1965).

GrN-4209. Mondoñedo I, Col. 58

$10,840 \pm 110$ $\mathbf{8 8 9 0}$ B.C.

$\delta C^{13}=-18.0 \%$

Fossil soil rich in charcoal, at ca. $3.5 \mathrm{~m}$ depth below recent black soil, in Sec. 1a. Taken in fan-like deposit on plateau W of lower part of principal canyon.

\section{GrN-4210. Mondoñedo II, Col. 59}

$10,760 \pm 160$ 8810 в.C.

Gray fossil soil rich in charcoal from upper part of canyon at ca. $7 \mathrm{~m}$ below recent black soil, in Sec. 2 .

General Comment: age of charcoal in soil complexes is same as that of Aller $\phi \mathrm{d}$ soil layer of NW Europe. Charcoal is attributed to forest fires of trees which presumably were dead as consequence of strong climatic 
changes shown by pollen diagram. Thus dated layers represent interstadial and transition towards last cold stadial (van der Hammen, 1965).

\section{Sabana de Bogotá, Section CUG series, Bogotá, Colombia}

Sec. in Sabana de Bogotá, near Inst. Geol. Nac. at Ciudad Univ. (4 $35^{\prime} \mathrm{N}$ Lat, $74^{\circ} 5^{\prime} \mathrm{W}$ Long), $2560 \mathrm{~m}$ alt, Bogotá, Colombia. This new Sec. CUG lies some hundred $m$ from Sec. CUX (or X) described and discussed by van der Hammen and González (1960). Samples belong to upper and lower part of dark stratum 300 to $340 \mathrm{~cm}$ deep. CUG pollen sec. described by van der Hammen (1966). Same layer in CUX dated K-568: 23,850 \pm 600 (Radiocarbon, 1960, v. 2, p. 17). Coll. 1959 and subm. by $\mathrm{T}$. van der Hammen.

\section{GrN-4417. Sabana de Bogotá, Col. 38}

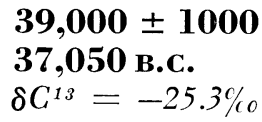

Peaty humic clay from lower part of layer, between 300 and $320 \mathrm{~cm}$.

\section{GrN-4214. Sabana de Bogotá, Col. 39}

$35,400 \pm 1160$ 33,450 в.C. $\delta C^{13}=-25.2 \%$

Peaty humic clay from upper part of layer, between 300 to $320 \mathrm{~cm}$. General Comment: dates show large discrepancy with K-568. This could be explained by assumption that dark stratum represents long span of time. Dates suggest considerable lowering of lake level shortly before 39,000 в.P.

\section{GrN-4657. La Candelaria, Col. 60, Cundinamarca, 40,250 B.c. Colombia}

Humic clay with abundant charcoal from Ladrillería La Candelaria (ca. $4^{\circ} 30^{\prime} \mathrm{N}$ Lat, $74^{\circ} \mathrm{W}$ Long), alt ca. $2580 \mathrm{~m}$, near Tunjuelito, $\mathrm{S}$ of Bogotá, dept. of Cundinamarca, Colombia. Coll. from exposure, $3 \mathrm{~m}$ below surface, dates upper part of "high-terrace" shortly before level of savanna-lake sank below terrace (van der Hammen, 1966). Coll. 1962 and subm. by T. van der Hammen. Comment: only acid pretreatment.

\section{GrN-4385. Río Meta, Puerto López, Col. 37, $\quad 150 \pm 40$ Meta, Colombia \\ A.D. 1800 \\ $\delta C^{13}=-28.3 \%$}

Charcoal from sec. in eroded bank of Meta R. at site of ferry boat near Puerto López ( $4^{\circ} 06^{\prime} \mathrm{N}$ Lat, $7^{\circ} 58^{\prime} \mathrm{W}$ Long), at ca. $200 \mathrm{~m}$ alt, in Llanos Orientales, dept. of Meta, Colombia. Sediments were deposited during high water. Sample belongs to horizon with layer of charcoal. Sec. was $18 \mathrm{~cm}$ long and sample $2 \mathrm{~cm}$ thick. Coll. 1958 and subm. by T. van der Hammen. Comment: vegetational changes caused by human destruction of forest by fire seem related to increasing colonization of Llanos. 
Pollen analyses show extension of savanna in part of destroyed forest region (Wijmstra and van der Hammen, 1966). From known secular variations in $\mathrm{C}^{14}$, estimated historical date is A.D. 1650 to A.D. 1840. Date publ. in description of sec. must be altered.

\section{Laguna de Agua Sucia series, Meta, Colombia}

Sec. in Laguna de Agua Sucia $\left(3^{\circ} 30^{\prime} \mathrm{N}\right.$ Lat, $73^{\circ} 40^{\prime} \mathrm{W}$ Long), in Llanos Orientales at SW of locality of San Martín, dept. of Meta, Colombia. Pollen analyses described and interpreted by Wijmstra and van der Hammen (1966).

Lake is at $+260 \mathrm{~m}$, near intersection of valley of Ariari $\mathrm{R}$. and Alto Llano tableland, mainly covered with open grass-sedge savanna. Core is $5 \mathrm{~m}$ long, starting $1 \mathrm{~m}$ below water level; samples from peat layers at 35 to $65 \mathrm{~cm}$ and 240 to $290 \mathrm{~cm}$ depth. Pollen zones are provisionally identified by alphabetic nomenclature to be used for pollen zones of Llanos Orientales. Coll. 1958 and subm. by T. van der Hammen.

\section{GrN-4416. Laguna de Agua Sucia, Col. 27

$$
\begin{gathered}
2210 \pm 35 \\
260 \text { B.C. }
\end{gathered}
$$$$
\delta C^{13}=-28.1 \%
$$

Peat interspersed with clay, from 50 to $60 \mathrm{~cm}$ below bottom of lake. Pollen Zone Z. Comment: date publ. by Wijmstra and van der Hammen (1966) under same number is to be corrected.

GrN-3601. Laguna de Agua Sucia, Col. 36

$$
2340 \pm 90
$$$$
390 \text { B.C. }
$$

Peat interspersed with clay, from 60 to $70 \mathrm{~cm}$ below bottom of lake. Pollen Zone $\mathrm{Z}$.

GrN-4213. Laguna de Agua Sucia, Col. 28

Peat interspersed with clay, from 250 to $260 \mathrm{~cm}$ below bottom of lake. Pollen Zone W.

GrN-3522. Laguna de Agua Sucia, Col. 30

$4110 \pm 70$

2160 B.c.

Peat interspersed with clay, from 270 to $280 \mathrm{~cm}$ below bottom of lake. Pollen Zone W. Comment: only acid pretreatment.

General Comment: dates allow estimate of sedimentation rate at $12 \mathrm{~cm} /$ $100 \mathrm{yr}$. Ages calculated from this rate permit correlation with European paleoclimate, showing pollen succession from open savanna at beginning of European Sub-Boreal, savanna woodland or dry forest at end of European Sub-Boreal, extension of forest at beginning of European SubAtlantic, and replacement by open savanna and open grass savanna during recent times due to action of man. Comparison with GrN-4122: 2050 \pm 50 in Laguna de la Herrera series (this list) suggests contemporaneity of dry climate period and beginning of sedimentation ca. 5000 B.P. (Wijmstra and van der Hammen, 1966). 
D. Guyana

\section{Ogle Bridge series, Georgetown, Guyana}

Pollen sec. at Ogle Bridge ( $6^{\circ} 50^{\prime} \mathrm{N}$ Lat, $58^{\circ} 10^{\prime} \mathrm{W}$ Long), Georgetown, Guyana, $34 \mathrm{~m}$ deep. Two samples taken from Borehole 39, above and below brown mottled layer intercalated in gray clay. Mottled layer indicates a sea regression expected to be Würm-Glacial according to pollen analysis (van der Hammen, 1961, 1963). Coll. 1958 and subm. by T. van der Hammen.

GrN-3058. Ogle Bridge, B.G. 4

$8590 \pm 65$

Peaty clay at $20.5 \mathrm{~m}$ depth.

GrN-3506. Ogle Bridge, B.G. 5 6640 в.c.

Hard peaty clay with wood fragments at $29 \mathrm{~m}$ depth. General Comment: from estimated sedimentation rate of $23 \mathrm{~cm} / 100 \mathrm{yr}$ an early Holocene transgression at $22.5 \mathrm{~m}$ below sea level dates to 9500 B.P. which correlates exactly with similar transgression in Netherlands (van der Hammen, 1963). Only acid pretreatment.

\section{GrN-3103. Kwakwani Canal, B.G. 3, Berbice, $\quad 6490 \pm 80$ Guyana \\ 4540 B.C.}

Peaty clay from Kwakwani Canal $\left(5^{\circ} 15^{\prime} \mathrm{N}\right.$ Lat, $58^{\circ} 12^{\prime} \mathrm{W}$ Long) in flood plain of Berbice R., dist. of Berbice, Guyana. Canal is flanked by a terrace (2.5 m above water level) of clay, silt, sand and, sloping towards river, a peat layer which corresponds to a short transgression. Sample, $7 \mathrm{a}$ and 8 (van der Hammen, 1963), is from base of peaty clay at ca. $1.80 \mathrm{~m}$ depth below terrace level. River level is ca. $+7.5 \mathrm{~m}$. Coll. Nov. 1958 and subm. by T. van der Hammen. Comment: date agrees with dates of Torani Canal and Oreala (see below). Maximum sea level ca. 6500 в.P. was at least $2.5 \mathrm{~m}$ above present level. Only acid pretreatment.

\section{$\begin{array}{lll}\text { GrN-3136. Torani Canal, B.G. 1, Berbice, Guyana } & 6140 \pm 75 \\ 4190 & \text { B.c. }\end{array}$}

Peat from Sec. I, 1.60 to $1.70 \mathrm{~m}$ depth (Sample 7) in $\mathrm{N}$ bank of canal between Berbice and Canje Rivers ( $5^{\circ} 50^{\prime} \mathrm{N}$ Lat, $57^{\circ} 30^{\prime} \mathrm{W}$ Long), dist. of Berbice, Guyana. Canal cuts through Coropina Formation, exposure rises ca. $3 \mathrm{~m}$ above water level (level of canal water is $+0.60 \mathrm{~m}$ ); peat layer from 0.75 to $2.30 \mathrm{~m}$ above high-water mark, both underlain and covered with mottled clay, belongs to this horizon. Coll. 1958 and subm. by T. van der Hammen. Comment: date corresponds to end of transgression (van der Hammen, 1963) and correlates pollen-analytically and in date with transgression phase of Kwakwani Canal (see above) and Oreala (see below). Only acid pretreatment.

\section{GrN-3109. Oreala, Corentyne River, B.G. 2, Berbice, $6470 \pm 85$ Guyana \\ 4520 в.c.}

Base of peat layer 3.70 to $3.90 \mathrm{~m}$ deep in gully. Sec. I (Sample 4) from clay in Coropina Formation exposed in bank of Corentyne (Couran- 
tyne) R., near Oreala (Orealla) (5 $5^{\circ} 13^{\prime} \mathrm{N}$ Lat, $57^{\circ} 15^{\prime} \mathrm{W}$ Long), dist. of Berbice, Guyana. Peat is from ca. $60 \mathrm{~cm}$ above water level which is +3 to $+4.5 \mathrm{~m}$. Coll. 1958 and subm. by T. van der Hammen. Comment: peat indicates transgression (van der Hammen, 1963). Date is same as for Kwakwani Canal (see above), also dating short transgression. From geologic considerations and this analysis, sedimentation rate of $25 \mathrm{~cm} / 100$ $\mathrm{yr}$ is estimated for Holocene sediments on top of Coropina Formation, which agrees with rate at Ogle Bridge series (see above). Only acid pretreatment.

\section{Lake Moriru series, Essequibo, Guyana}

Secs. for pollen analyses in lake Moriru (Moreiru) (ca. $4^{\circ} \mathrm{N}$ Lat, $59^{\circ} \mathrm{W}$ Long), at $110 \mathrm{~m}$ alt, $\mathrm{N}$ of Rupununi Savannas, S of Pakaraima hills, $2 \mathrm{~km} \mathrm{E}$ of Ireng R., Guyana. Most of area is covered by savanna and tree-savanna. Analyses described and interpreted by Wijmstra and van der Hammen (1966). Dating expected to give information about climatic changes and appearance of man in region. Samples coll. with sonde down to $6.5 \mathrm{~m}$ depth. Coll. 1964 and subm. by T. van der Hammen.

GrN-4581. Lake Moriru, B.G. 15

$5980 \pm 70$ 4030 B.C.

Humic clay from 105 to $115 \mathrm{~cm}$ depth. Comment: date publ. in description of sec. must be altered.

\section{GrN.4526. Lake Moriru, B.G. 16}

Humic clay from 165 to $195 \mathrm{~cm}$ depth.

$$
\delta C^{13}=-26.9 \%
$$

General Comment: 2 sedimentation rates are obtained for each part of core, $1.9 \mathrm{~cm} / 100 \mathrm{yr}$ and $5.7 \mathrm{~cm} / 100 \mathrm{yr}$, respectively. Pollen diagram is longest known from savanna and seems to reach Last Glacial period. Correlation seems to be possible with 2 pollen zonations determined for Colombia, namely Laguna de Agua Sucia and Cordillera Oriental (this list).

\section{E. Surinam}

\section{Langs Maratakka series, Nickerie, Surinam}

Peat from 3 sites near Maratakka R. ( $5^{\circ} 45^{\prime} \mathrm{N}$ Lat, $56^{\circ} 40^{\prime} \mathrm{W}$ Long), upstream of Wageningen, dist. of Nickerie, Surinam. Expected to date old ridges due to sea transgressions and beginning of peat formation of Coropina clay in W of Surinam. CUP (Cupido) lies at $25 \mathrm{~km}$, and MAR at $60 \mathrm{~km}$ from Wageningen. Described by Brinkman and Pons (1968). Coll. 1962 and subm. by L. J. Pons, Landbouw Hogeschool, Wageningen, Netherlands.

\section{GrN-4518. CUP 2-1}

$5130 \pm 70$ 3180 B.c.

Reduced peat from ca. $1.5 \mathrm{~m}$ below surface (at about present sea level) under gray reduced clay and "pegasse". 
GrN-4517. CUP 1-3

Recluced peat from ca. $4 \mathrm{~m}$ below surface (at ca. $-1.5 \mathrm{~m}$ ). Under thick sand layer $(2 \mathrm{~m})$ and peat $(2 \mathrm{~m})$ with intercalation of clay. Coropina clay lies under sampled peat layer.

GrN-4519. MAR 1-1

$6720 \pm 70$ 4770 B.C.

$\delta C^{13}=-26.1 \%$

Reduced peat from ca. $2.35 \mathrm{~m}$ below surface (at ca. $-2.5 \mathrm{~m}$ ). Taken from base of peat layer (in actual swamp-forest) resting immediately on Coropina clay. Pretreated only with acid.

General Comment: beginning of peat-formation on Coropina-surface occurs ca. 6500 B.P., which agrees with dates of transgression peat on Coropina in Guyana (GrN-3103, GrN-3109, GrN-3136, and GrN-4847, this list). These last dates were believed to date high relative sea level. Formation of oldest coastal bars appears to have started ca. 5000 B.P. Brinkman and Pons (1968) suggest correlation of dates from Guyana and Surinam in this and other lists.

GrN.4718. Onoribo, Suriname, Surinam

$$
\begin{aligned}
& >48,000 \\
\delta C^{13} & =-27.8 \%(c
\end{aligned}
$$

Charred wood, probably Rhizophora sp. (ONO IV-3 s) from excavation in Onoribo bauxite mine (5 $5^{\circ} 36^{\prime} 30^{\prime \prime} \mathrm{N}$ Lat, $55^{\circ} 9^{\prime} 30^{\prime \prime} \mathrm{W}$ Long), near Paranam, dist. of Suriname, Surinam. From ca. $3.50 \mathrm{~m}$ depth or +2.50 to $+2.60 \mathrm{~m}$. Sample was in stratum of gray completely reduced clay, without limestone and with pyrites. Described by Brinkman and Pons (1968). Coll. 1964 and subm. by L. J. Pons. Comment: sample dates Lelydorp clay on upper part of Coropina Formation, below Lelydorp beach-ridge sands. Lelydorp clay has been considered of interglacial age (last interglacial). A related date from Guyana is GrN-3506, $>45,000$ B.P. (this list).

\section{Matawaribo series, Suriname, Surinam}

Sec. MTW 4, $10 \mathrm{~m}$ long, from Matawaribo $\left(5^{\circ} 31^{\prime} \mathrm{N}\right.$ Lat, $55^{\circ} 8^{\prime}$ IV Long), $35 \mathrm{~km} \mathrm{~S}$ of Paramaribo, dist. of Suriname, Surinam. From boring in erosion gulley filled with Holocene sediments. Surface level is ca. $+\mathrm{l}$ to $+2 \mathrm{~m}$. Coll. 1963 by L. J. Pons and subm. by T. van der Hammen.

\section{GrN-4847. Matawaribo 4D}

$7240 \pm 100$ 5290 B.C.

Clayey peat in central part of core at 525 to $555 \mathrm{~cm}$ depth.

$$
\delta C^{13}=-23.8^{\%} \%
$$

\section{GrN-4848. Matawaribo $4 \mathrm{E}$}

$$
10,340 \pm 100
$$

8390 B.C.

$$
\delta C^{13}=-29.3 \%
$$

Peat from between 900 and $930 \mathrm{~cm}$ depth. Deepest layer of core underlain by sand. 
General Comment: (Roeleveld, 1969) Sample 4D dates the beginning of $100 \%$ mangrove elements in pollen profile, thus the ingression of the sea. Expected to date between 6500 and 7500 B.P. (compare GrN-3103, GrN-3109 and GrN-3136, for Guyana, this list). Sample 4E dates beginning of growth of peat. From date it follows that peat is not eustatic because on that time sea level was at least $25 \mathrm{~m}$ lower than at present.

\section{F. Argentina \\ GrN-4073. Delta Río Paraná, Buenos Aires, Argentina

$$
\begin{aligned}
& 8620 \pm 100 \\
& 6670 \text { B.C. }
\end{aligned}
$$$$
\delta C^{13}=-27.2 \%
$$

Peat taken in Boring 2, in Delta of Paraná R. (ca. $34^{\circ} 5^{\prime} \mathrm{S}$ Lat, $58^{\circ}$ $50^{\prime}$ W Long), near Campana, prov. of Buenos Aires, Argentina. Sample belonged to $20 \mathrm{~cm}$ thick layer of highly compressed peat, at ca. $-18 \mathrm{~m}$, $20 \mathrm{~m}$ below ground surface. Peat stratum is underlain by loess deposits and covered by thick layer of sea clay thought to belong to Querandinense Formation. Coll. and subm. by W. H. van der Molen. Comment: dates beginning of marine transgression in the area, corresponding to worldwide elev. of sea level.

\section{Atlantic Shoreline series, Buenos Aires, Argentina}

Atlantic Ocean transgressions investigated with samples from $\mathrm{E}$ coast, prov. of Buenos Aires, Argentina. Problem has been summarized by Frenguelli (1950). Coll. 1965 and subm. by C. R. Cortelezzi, Mus. de La Plata, La Plata, Argentina.

\section{GrN-5631. La Plata 2}

$$
\begin{gathered}
\mathbf{3 5 3 0} \pm \mathbf{3 5} \\
\mathbf{1 5 8 0} \text { B.C. } \\
\delta C^{13}=-2.0 \%
\end{gathered}
$$

Scattered fragments of shells from cut in clay along road, at $50 \mathrm{~cm}$ depth, near La Plata ( $34^{\circ} 52^{\prime} \mathrm{S}$ Lat, $57^{\circ} 55^{\prime} \mathrm{W}$ Long), prov. of Buenos Aires, Argentina. Ca. $6 \mathrm{~m}$ above present sea level, thought to belong to Querandinense or Platense Formations. Comment: diluted acid pretreatment. No correction for isotopic fractionation applied.

\section{GrN-5632. La Plata 3}

$$
\begin{gathered}
\mathbf{3 4 , 0 0 0} \pm \mathbf{5 0 0} \\
\mathbf{3 2 , 0 5 0} \text { в.C. } \\
\delta C^{13}=+0.1 \%
\end{gathered}
$$

Shells from layer at ca. $3.40 \mathrm{~m}$ depth, ca. $+9 \mathrm{~m}$, in excavation near La Plata (34 $52^{\prime} \mathrm{S}$ Lat, $57^{\circ} 55^{\prime} \mathrm{W}$ Long), prov. of Buenos Aires, Argentina. Thought to belong to Belgranense ingression. Comment: diluted acid pretreatment. No correction for isotopic fractionation applied.

\section{GrN-5678. La Plata 7}

$35,700 \pm 900$

33,800 B.C.

$\delta C^{13}=-0.8 \%$

Scattered fragments of shells from layer 20 to $50 \mathrm{~cm}$ thick, at ca. $1 \mathrm{~m}$ depth, ca. $+10 \mathrm{~m}$, in excavation in intersection of Sts. 122 and 58 in La Plata (34 $52^{\prime} \mathrm{S}$ Lat, $57^{\circ} 55^{\prime} \mathrm{W}$ Long), prov. of Buenos Aires, Argentina. Thought to belong to Belgranense ingression, thus of similar age 
to La Plata 3 (see above). Comment: date agrees with expectation. Diluted acid pretreatment. No correction for isotopic fractionation applied.

General Comment: several authors have referred to samples dating Atlantic Ocean level: Auer (1963; Radiocarbon, 1969, v. 11, no. 2, in press), Fray et al. (1963), Richards and Broecker (1963), Shepard (1963, 1964), Emery and Garrison (1967), and C. M. Urien (cited in Radiocarbon, 1967, v. 9, p. 273). Collector thinks that it is not yet possible to correlate La Plata 2 with other samples owing to scarcity of data and uncertainties about Querandinense and Platense transgressions in different localities. In particular, collector's opinion is that dating of sea level (L-628: $>35,000$ B.P. Radiocarbon, 1961, v. 3, p. 152) by Richards and Broecker (1963) is doubtful due to possible displacement of shells from original depth by sea. Sample Delta Río Paraná (see above) is considered perhaps to date older ingression. Samples from Palo Blanco (this list) are considered by collector to date Platense ingression, and date of Punta del Indio (Radiocarbon, 1967, v. 9, p. 273) is not considered acceptable if compared with date for same site of ca. 5880 B.P. (IVIC-unpubl.), although no stratigraphic positions are mentioned.

\section{ARCHAEOLOGIC SAMPLES}

\section{A. Panama}

\section{Western Panama series, Panama}

Two samples frequently discussed in literature concerning ceramic cultures in W and Central Panama. Coll. 1955 by H. Feriz and collaborators; subm. by H. Feriz, Koninginneweg 50, Amsterdam, Netherlands.

\section{GrN-1516. El Volcán, Chiriquí, Panama}

Charcoal from below layer of volcanic ash at El Volcán $\left(\right.$ ca $9^{\circ} \mathrm{N}$ Lat, $82^{\circ} 30^{\prime} \mathrm{W}$ Long), $\mathrm{S}$ of continental divide, prov. of Chiriquí, Panama. Feriz (1959a, 1959b, 1961) described site and reported assoc. with "Tabasará ceramics." Comment: since publication of date by Feriz it has been frequently allocated to another site (Pueblo Nuevo or Puerto Nuevo, see sample below) by Lothrop (1959), Baudez (1963), Ladd (1964), and Linares de Sapir (1966, 1968a). Implications of date for dating Scarified ware are discussed by Haberland (1962) and by Linares de Sapir (1968a, 1968b). Both question assignment of Scarified ware of potsherds publ. by Feriz (1961, p. 21, figs. 5, 6) and described by Lothrop (1959). Only acid pretreatment.

\section{GrN-1520. Pueblo Nuevo, Chiriquí, Panama A.D. 1620}

$\mathbf{3 3 0} \pm \mathbf{5 0}$

Charcoal from Mound A, near village Pueblo Nuevo (ca. $8^{\circ} \mathrm{N}$ Lat, $81^{\circ} 30^{\prime}$ W Long), W of Tabasará R., ca. $20 \mathrm{~km}$ from Pacific Ocean, on S slope of Quebrada de Manay near border with prov. of Veraguas, Panama. Coll. from thin layer of charcoal and ash in excavated tumulus. Assoc. finds described by Feriz (1959a, 1959b, 1961). Comment: date not previously reported in literature. From known secular variations of $\mathrm{C}^{14}$, 
historical date is estimated to fall between A.D. 1470 and A.D. 1540 (see Introduction). Only acid pretreatment.

General Comment: another date frequently cited together with these 2 is GrN-2200: $1125 \pm 65$ B.P. or A.D. $825 \pm 65$ from Venado Beach, Panama (Radiocarbon, 1964, v. 6, p. 365). Sample coll. and subm. by K. S. Lothrop, Peabody Mus., Harvard Univ., Cambridge, Massachusetts. Considerable confusion has arisen in literature concerning allocation of samples to sites and corrections for industrial effect. Submitter rejected original figure of $90 \pm 50$ B.P. for Pueblo Neuvo as being too young and ascribed sample to activity of huaqueros (Feriz, 1959a, 1959b, 1961). Figures given here are corrected values based on NBS standard activity (Radiocarbon, 1963, v. 5, p. 164) and supersede all other values cited in literature (compare Lothrop, 1959, 1960, 1966; Feriz, 1959a, 1959b, 1961; Baudez, 1963; Haberland, 1962; Ladd, 1964; Linares de Sapir, 1966).

\section{B. Colombia \\ GrN-4902. La Lusitania, I.C.A.-9a, Boyacá, Colombia}

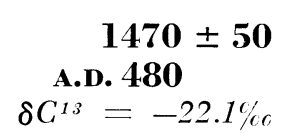

Cotton cloth from burial site at base of high rock at Hacienda La Lusitania (ca. $6^{\circ} 33^{\prime} \mathrm{N}$ Lat, $72^{\circ} 30^{\prime} \mathrm{W}$ Long) near Chiscas, $\mathrm{N}$ of Boyacá, dept. of Boyacá, Colombia. Used as wrap for mummy of young person buried $60 \mathrm{~cm}$ below surface level underneath slabs. Assoc. with charcoal, cords made of fique (Furcraea sp.) and hair (probably human). Dates Lache culture, still prevalent in region during Conquest. This culture, described by Silva Celis (1945) had some practices in common with Chibcha, such as mummification. Coll. 1943 by E. Silva Celis, Univ. Pedagógica Tecnol. Col., Tunja, Colombia; subm. by T. van der Hammen.

\section{Los Solares series, Boyacá, Colombia}

Site at Los Solares (ca. $6^{\circ} \mathrm{N}$ Lat, $73^{\circ} \mathrm{W}$ Long), near Sogamoso, dept. of Boyacá, Colombia, belongs to pre-Columbian culture known as Chibcha or Muisca, characterized by elaborate political organization and religion. Agriculture and commerce were also well developed (Angulo Val(lés, 1963). Subm. by T. van der Hammen.

\section{GrN-4903. Los Solares, I.C.A.-10}

$$
\begin{array}{r}
\mathbf{8 5 0} \pm \mathbf{5 0} \\
\text { A.D. } 1100 \\
\delta C^{13}=-25.2 \%
\end{array}
$$

Wood (probably guayacán) from fragment of column of Chibcha building. Probably found in one of several deep holes with remnants of thick wooden poles thought to belong to Temple of the Sun and assoc. with charcoal and mineral coal. Coll. 1924 and kept since then in Mus. de Arqueología, Sogamoso, Boyacá, Colombia. Subm. 1966.

\section{GrN-4730. Los Solares, I.C.A.-7}

$$
\begin{aligned}
& \mathbf{1 3 5 0} \pm \mathbf{5 0} \\
& \text { A.D. 600 } \\
& \delta C^{13}=-25.4 \%
\end{aligned}
$$

Wood from center of Sec. 3, $1.75 \mathrm{~m}$ below surface level and $1 \mathrm{~m}$ below Level 3. Sample belonged to vertical nucleus of wood surrounded 
by stones. It should date rite of burying stones in holes of different sizes, also practiced in Central America (Silva Celis, written commun., 1968). Assoc. with triturated stone, potsherds, mineral coal, and some animal bones. Coll. 1965 by E. Silva Celis. Comment: complete pretreatment left too little material and hence alkaline extract had to be dated. True age of sample could thus be older. From depth of find collector expected older age.

\title{
GrN-4729. Los Solares, I.C.A.-5
}

$1640 \pm 50$

\author{
A.D. 310
}

$\delta C^{13}=-11.3 \%$

Charred maize grains from shallow deposit $35 \mathrm{~cm}$ in diam., $40 \mathrm{~cm}$ deep in NE of Sec. 1, between Levels 3 and $4(90 \mathrm{~cm}$ below surface) of excavation. Grains were surrounded by ash and wood charcoal. Mouth of hole was sealed with tamped clay. This is considered to have been offering of grain to Chibcha deities because it lies in center of Ciudad Muisca del Sol, probably near Temple of the Sun, set on fire by Spaniards when arriving at Sogamoso (Silva Celis, 1968). Potsherds, lithic tools, and objects made of tumbaga gold-copper alloy occurred in same context. Coll. by E. Silva Celis. Comment: oldest date for Chibcha or Muisca culture on Colombian plateau, older than suggested in previous schemes (Angulo Valdés, 1963). Collector thinks date will permit estimate of age of ceramics, rock art, textiles, and also of Bochica's myth (Silva Celis, 1968). Age has been corrected for isotopic fractionation (see Introduction).

General Comment: it seems proven that Chibcha or Muisca culture extends over $2000 \mathrm{yr}$ and overlaps in time with San Agustín culture (this list).

\section{El Abra II series, Cundinamarca, Colombia}

Valley of El Abra (5 $5^{\circ} 1^{\prime} \mathrm{N}$ Lat, $73^{\circ} 57^{\prime} \mathrm{W}$ Long), between Susagua and Barandillas Rivers and Tibitó R., Sabana de Bogotá, dept. of Cundinamarca, Colombia. Contains several rock shelters formed by erosion. One of them, el Abra II, N of W escarpment of valley, was described in report on excavation by van der Hammen and Correal (1967) cited by Hurt (1968). Characteristics of strata: Level 1 ( 0 to $25 \mathrm{~cm}$ below floor level), grayish-brown clayish soil, containing potsherds of Chibcha style. Level 2 and $3(25$ to $75 \mathrm{~cm})$, brownish clay with sand and rock fragments, containing some stone artifacts. Levels 4 and $5(75$ to $125 \mathrm{~cm})$, containing similar material as Level 3 on base of sandy clay and organic materials. Levels 6,7 , and $8(125$ to $200 \mathrm{~cm})$, dark layer with rock fragments, containing stone artifacts. Level $9(200$ to $225 \mathrm{~cm})$ is continuation of Level 8 and contains fewer artifacts. Artifact content of lower levels $(10,11$, and 12) has not been determined. Pollen studies in progress seem to confirm that more minerogene intercalations of Levels 4, 5, and 6 are due to colder conditions corresponding to European Pre-Boreal and Younger Dryas time (van der Hammen, written commun., 1968). Coll. 
1967 by T. van der Hammen and G. Correal; subm. by T. van der Hammen.

\section{GrN-5561. El Abra II, Level 5, Col. 83}

$$
\begin{aligned}
& 9340 \pm 90 \\
& 7390 \text { в.c. } \\
& \delta C^{13}=-20.8 \%
\end{aligned}
$$

Dark soil with fine charcoal from Level 5 , in which 30 stone artifacts were found.

\section{GrN-5556. El Abra II, Level 7, Col. 85}

$$
\begin{gathered}
12,400 \pm 160 \\
10,450 \text { в.c. } \\
\delta C^{13}=-25.7 \%
\end{gathered}
$$

Dark soil with fine charcoal from Level 7 , in which 9 stone artifacts were found.

\section{GrN-5557. El Abra II, Level 8, Col. 86}

$9420 \pm 110$

Dark soil with fine charcoal from Level 8 , in which 5 stone artifacts were found.

General Comment: this is one of oldest preceramic sites in South America. Only one other site of comparable age is known with dated remains and definitely assoc. with human occupation (Hurt, 1968), Laguna de Tagua Tagua in Central Chile, GX-1205 (unpubl.): 11,380 \pm 320 (Montané, 1968; Mostny, 1968). Other related dates are listed and critically reviewed by Haynes (1967). Artifacts in El Abra II, scrapers, knives, drills, perforators, and projectile points mostly triangular, were mainly made by percussion flaking from banded chert (Levels 2 to 7 ) and Cretaceous sandstone (Levels 8 and 9). As fine charcoal in samples was mixed with very fine rootlets, perhaps modern, dates should be taken as minimum. Thus Col. 85 seems more reliable than Col. 86. In Level 9, not dated but probably older, stone artifacts are still present.

\section{GrN-4004. Laguna de Chisacá, I.C.A.-3, $1110 \pm 60$ Cundinamarea, Colombia A.D. 840}

Charcoal with clay, from Laguna de Chisacá $\left(4^{\circ} 20^{\prime} \mathrm{N}\right.$ Lat, $74^{\circ} 20^{\prime}$ W Long), S of Bogotá, dept. of Cundinamarca, Colombia. Found inside copper-shell in small cave under water level of lake and expected to clate early phase of Chibcha culture. Coll. 1959 by L. Duque Gómez, Inst. Colombiano Antropol., Bogotá, Colombia; subm. by T. van der Hammen. Comment: for correlation of human occupation and pollen secs., see van der Hammen and González (1965a) and dated Laguna de la Herrera series (this list). Only acid pretreatment.

\section{San Agustín series, Huila, Colombia}

Several samples representing San Agustín culture, from different sites near San Agustín ( $1^{\circ} 53^{\prime} \mathrm{N}$ Lat, $76^{\circ} 14^{\prime} \mathrm{W}$ Long), alt $1700 \mathrm{~m}$, S of dept. of Huila, in Higher Magdalena Valley, Colombia. Sites in Parque Nacional Arqueológico de San Agustín are known as Mesita B (in center), Alto de Lavapatas (in SW) and Potrero de Lavapatas (in S of park). Area was supposed to have been important religious center. 
About 30 sites are known for this culture, characterized by gigantic sculptures and architecture (Preuss, 1929; Pérez de Barradas, 1943) with influences both from Mesoamerican and Peruvian cultures. Agriculture (mainly maize, several cobs of which were found) was probably welldeveloped. See also pollen profile of van der Hammen (1962) referred to in Laguna de los Bobos series (this list). Large amount of manos and milling stones, several styles of pottery, and a few obsidian and basalt flakes were found. Metallurgy of copper and gold was known but not as well-developed as in other Colombian cultures.

The San Agustín culture was recently described by Duque Gómez (1963, 1964-1966) and its ceramics by Patterson (1965). Samples subm. by T. van der Hammen.

\section{GrN-3647. Potrero de Lavapatas, I.C.A.-1 A.D. 1180}

$770 \pm 120$

Wood charcoal excavated in Room BIII in SE sector of Potrero de Lavapatas, 2nd level, $4 \mathrm{~cm}$ below surface. Hearth was found in $\mathrm{NE}$ of dwelling together with potsherds, stone flakes, and charred vegetables, peanuts, maize, etc. Holes in floor suggest that dwelling consisted of 2 circular houses of ca. $3 \mathrm{~m}$ diam. Coll. 1957 by L. Duque Gómez. Comment: sample thought to correspond to later period of San Agustín culture. Only acid pretreatment.

\section{GrN.3643. Mesita B, I.C.A.-2}

$$
1930 \pm 50
$$

A.D. 20

Charcoal from Level 2 at base of NW mound, Mesita B. Assoc. with potsherds, stone flakes, and unidentified vegetables. Depth, 3.70 to 3.90 $\mathrm{m}$ below apex of artificial mound (diam. ca. $18 \mathrm{~m}$ ) with 2 different strata. Excavated by Duque Gómez (1964-1966) who described and compared finclings with those of Pérez de Barradas (1943). Coll. 1960 by L. Duque Gómez. Comment: another date for similar material from same layer is $1800 \pm 100$ B.P. (I-unpubl.). Charcoal from grave built before construction of mound was dated $1525 \pm 150$ B.P. (I-unpubl.). Both dates are discussed by Duque Gómez (1964-1966). Samples, older than expected, do not date construction of mound, which seems to consist of older refuse from nearby dwellings. Only acid pretreatment.

GrN-4206. Mesita B, I.C.A.-4

$1960 \pm 50$

10 B.C.

Wood charcoal from Refuse Mound E of Mesita B, Sec. BVI, Level 2, $40 \mathrm{~cm}$ depth. Ceramics, calcite beads, fragment of gold foil and other refuse of metallurgical industry assoc. with sample. Refuse heap was probably accumulated in densely populated area and transformed into artificial plateau to be used as burial site. Coll. 1960 by L. Duque Gómez. Comment: date is of importance for pre-Columbian metallurgy.

GrN-3016. Alto de Lavapatas, AL

Wood (Col. 4), found in Tomb 7 at site Alto de Lavapatas, from either sarcophagus, litter, or canoe. Described and illustrated by excavator 
(Pérez de Barradas, 1943, pl. 162). Board was $213 \mathrm{~cm}$ long and $33 \mathrm{~cm}$ broad. Grave consisted of circular pit with underground side chamber. Assoc. with ceramics and human bones. Coll. 1937 by Pérez de Barradas and kept in local mus. Sample subm. in 1956. Comment: 1st and, as yet, oldest radiocarbon date for San Agustín culture. Only acid pretreatment. General Comment: on basis of these analyses Patterson (1965) gives tentative dates for ceramic sequences of Pérez de Barradas (1943): Lavapatas phase, 6th century B.C.; Mesita phase, near A.D. 100; Bolaños, not earlier than 5th century A.D.; and Quinchana phase, A.D. 1200. Patterson (1965) analyzes correlation of San Agustín pottery with Tierradentro ware from NW of dept. of Cauca, Colombia, and considers possible influences from Ecuador. Duque Gómez (1963, 1964-1966) divides culture into 3 phases and suggests their limits; Mesitas Inferior/Mesitas Medio, A.D. 500; Mesitas Medio/Mesitas Superior, A.D. 1200. Some of figures given for dates and for analyses number have been erroneously quoted in literature.

\section{Surinam}

\section{GrN-4551. Wonotobo, Nickerie, Surinam}

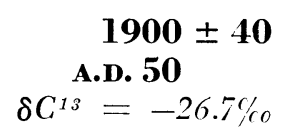

Charcoal from excavation (Pit 4, SW trail) near Wonotobo Falls (ca. $4^{\circ} 25^{\prime} \mathrm{N}$ Lat, $57^{\circ} 50^{\prime} \mathrm{W}$ Long), Corantijn (Courantyne) R., dist. of Nickerie, Surinam. Found in scattered fragments at 55 to $100 \mathrm{~cm}$ depth in clay horizon with coarse sand. Assoc. potsherds of Mabaruma phase or Barrancas style known from NW coast of Guyana and in Delta of Orinoco R. Bones of game and fish and some stone implements were also found. Coll. 1962 and subm. by D. C. Geijskes, Surinaams Mus., Paramaribo, Surinam, and Rijksmus. Nat. Hist., Leiden, Netherlands. Comment: 1st time this pottery style has been found in interior and lst date for this culture, expected to be ca. 1300 B.P.

\section{GrN-4552. Tingiholo schelprits, Suriname, $\quad 970 \pm 50$ Surinam \\ A.D. 980 \\ $\delta C^{13}=-26.6 \%$}

Charcoal from grave in Tingiholo schelprits, shell ridge (old sea wall), Pit 15 (ca. $5^{\circ} 50^{\prime} \mathrm{N}$ Lat, $55^{\circ} 15^{\prime} \mathrm{W}$ Long), at Kwatta, W of Paramaribo, dist. of Suriname, Surinam. Charcoal found scattered inside grave at $75 \mathrm{~cm}$ below surface level and assoc. with shells, stone implements, and human skeletons; Arawak settlement. Expected to be of same age as Hertenrits, GrN-1898: $1130 \pm 45$; GrN-1897: $1265 \pm 60$; GrN-845: $1045 \pm 60$ (Radiocarbon, 1964, v. 6, p. 365). Coll. 1961 and subm. by D. C. Geijskes.

\section{GrN-4414. Zanderij, Suriname, Surinam}

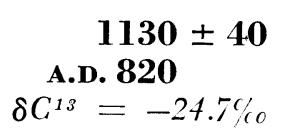

Charcoal (Za 10645/a) from near Zanderij (ca. $5^{\circ} 30^{\prime} \mathrm{N}$ Lat, $55^{\circ}$ $10^{\prime} \mathrm{W}$ Long), in savanna on rd. to village of Hannover, dist. of Suriname, 
Surinam. From 40 to $60 \mathrm{~cm}$ depth in quartz sand, assoc. with potsherds of Koriabo type (Cariban). Coll. 1961 and subm. by D. C. Geijskes.

\section{GrN-4241. Christiaan-Kondre, Marowijne, $\quad 440 \pm 50$ Surinam \\ A.D. 1510 \\ $\delta C^{13}=-26.2 \%$}

Charcoal (MCh 15427) from coast of Marowijne R., near mouth (ca. $5^{\circ} 45^{\prime} \mathrm{N}$ Lat, $54^{\circ} \mathrm{W}$ Long), dist. of Marowijne, Surinam, from 40 $\mathrm{cm}$ below surface of coarse sand on river bank. Assoc. with large number of potsherds with incised ornaments of different style, probably Cariban. Coll. $196 \mathrm{I}$ and subm. by D. C. Geijskes. From known secular variations in $\mathrm{C}^{14}$, estimated historical date is between A.D. 1420 and A.D. 1470.

\section{GrN-4239. Moengo Boesmanhill, Marowijne, Surinam}

$970 \pm 70$ A.D. 980

$\delta C^{13}=-26.2 \%$

Charred wood and palm seeds (MoBo 15570) from bauxite heap in lateritic clay mixed with sand and stones (ca. $5^{\circ} \mathrm{N}$ Lat, 54 $20^{\prime} \mathrm{W}$ Long), near Moengo, dist. of Marowijne, Surinam. Sample associated with potsherds and a few stone artifacts. Depth 30 to $45 \mathrm{~cm}$ below surface. Potsherds were of Koriabo type, described for NW Guyana, and similar to those found in Cometwana (Commetewana) creek in Commewijne dist. (Geijskes, 1960-1961), dated GrN-1899: 1310 \pm 45 (Radiocarbon, 1964 , v. 6, p. 365$)$. Coll. 1961 and subm. by D. C. Geijskes.

\section{GrN-4240. Bigiston, Marowijne, Surinam A.D. 1540 \\ $\delta C^{13}=-28.7 \%$}

$410 \pm 60$

Charcoal (MB 15426) from $40 \mathrm{~cm}$ depth in square of village on left bank of Marowijne (Maroni) R. (5 $25^{\prime} \mathrm{N}$ Lat, $54^{\circ} 05^{\prime} \mathrm{W}$ Long), dist. of Marowijne, Surinam. Large quantity of richly ornamented sherds with appliqués of unknown style was excavated. Coll. 1961 and subm. by D. C. Geijskes. Estimated historical date, from $\mathrm{C}^{14}$ correction curve, is between A.D. 1430 and A.D. 1490, or A.D. 1580.

\section{Peru}

\section{GrN-5474. Huaca Menor, Lambayeque, Peru}

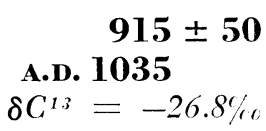

Partially charred wood from Huaca Menor, near Huaca La Ventana (ca. $8^{\circ} 26^{\prime} \mathrm{S}$ Lat, $79^{\circ} 53^{\prime} \mathrm{W}$ Long), Batán Grande, dept. of Lambayeque, Peru. Sample is piece of bow found at $20 \mathrm{~m}$ depth in tomb belonging to huaca. Site, excavated in 1967 by A. Pedersen, had been disturbed by huaqueros. Assoc. finds: 2 other bows, 17 human skeletons, thousands of copper "neipes" (double-tee copper money) of pure title (99.6\% Cu), wooden sceptres, gold foils, wooden arrow shafts, discs of shells, one necklace of white quartz beads, and one ceramic vessel of type called huaco rey. Ascribed by excavator to Lambayeque culture (Pedersen, in preparation). Wood of sample is probably Prosopis sp. (D. Cozzo, written 
commun.). Coll. 1967 and subm. by A. Pedersen, Paraguay 1480, Buenos Aires, Argentina. Comment: sample dates archery and copper refining techniques in Lambayeque culture. Tentative chronology of metallurgy publ. by Pedersen (1966).

\section{Lauricocha Cave L-2 series, Huánuco, Peru}

Cave near Casa Hacienda Lauricocha $\left(10^{\circ} 17^{\prime} \mathrm{S}\right.$ Lat, $76^{\circ} 40^{\prime} \mathrm{W}$ Long), in $\mathrm{N}$ highlands near sources of Marañón and Amazon Rivers, at $3930 \mathrm{~m}$ alt, $2 \mathrm{~km}$ E of Lake Lauricocha, dept. of Huánuco, prov. Dos de Mayo, Peru.

Three caves, L-1, L-2, and L-3, lie on W side of Antarragá moraine. Cave L-2 has been excavated since 1959 by Cardich (1964). Most of strata contain very fine charcoal and ash, large amounts of humic substances, cutin, carbonates, and other minerals (Teruggi and Cetrángolo, 1964). Eleven human skeletons were found in cave.

Deepest level, preceramic hunters, or Lauricocha I, assoc. with flaked tools, dated $9525 \pm 250$ B.P. (I-unpubl.). Another date for equivalent level in Cave U-1, ca. $5 \mathrm{~km}$ from L-2, is $8140 \pm 140$ B.P. (I-unpubl.).

A new excavation was carried out in July 1967 in rear part of cave, in 32 strata which show sequence similar to that publ. by Cardich (1964). Uppermost stratum with human occupation contains Inca ceramics; walls of cave are decorated with pictographs.

In some of samples humic extracts separated from residue (charcoal, etc.) were also dated as well as 2 carbonate portions. These are considered to contain mixture of Cretacic fossils, Last Glaciation stalactites, and precipitated carbonates (Teruggi, Andreis, and Cardich, written commun., 1968). Coll. 1967 and subm. by A. Cardich, Mus. de La Plata, Argentina.
GrN-5487. Lauricocha Cave L-2, Layer 12, $1080 \pm 90$ residue A.D. 870$$
\delta C^{13}=-24.2 \%
$$
GrN-5560. Lauricocha Cave L-2, Layer 12, humic extract
$1500 \pm 280$ A.D. 450
$\delta C^{13}=-24.4 \% c$

\section{GrN-5515. Lauricocha Cave L-2, Layer 12, carbonates}

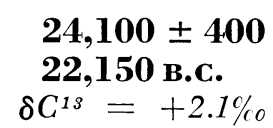

Sediments from 0.85 to $1.00 \mathrm{~m}$ below floor of cave. Assoc. with ceramic culture, Lauricocha V. Comment: date of carbonates fraction has not been corrected for isotopic fractionation.

\section{GrN-5582. Lauricocha Cave L-2, Layer 14}

$$
\begin{array}{r}
1640 \pm 70 \\
\text { A.D. 310 } \\
\delta C^{13}=-23.4 \% o
\end{array}
$$

Sediments from 1.10 to $1.30 \mathrm{~m}$ depth. Assoc. with ceramic culture, Lauricocha V. Comment: only acid pretreatment. 
GrN-5583. Lauricocha Cave L-2, Layer 18

$$
\begin{aligned}
& 1570 \pm 60 \\
& \text { A.D. 380 } \\
& \delta C^{13}=-23.4 \%
\end{aligned}
$$

Sediments from 1.45 to $1.55 \mathrm{~m}$ depth. Assoc. with ceramic culture, Lauricocha V. Comment: only acid pretreatment.

GrN-5493. Lauricocha Cave L-2, Layer 24, residue

$$
\begin{aligned}
\mathbf{4 2 6 0} \pm \mathbf{2 5 0} \\
\mathbf{2 3 1 0} \text { в.C. } \\
\delta C^{13}=-23.3 \% \\
\mathbf{4 6 2 0} \pm \mathbf{3 5 0} \\
\mathbf{2 6 7 0} \text { в.C. } \\
\delta C^{13}=-23.5 \% \text {. }
\end{aligned}
$$

GrN-5559. Lauricocha Cave L-2, Layer 24, humic extract

\section{GrN-5516. Lauricocha Cave L-2, Layer 24, $\quad \mathbf{2 8 , 3 5 0} \pm 440$ carbonates$$
\text { 26,400 B.C. }
$$$$
\delta C^{13}=+1.8 \% c
$$

Sediments from 2.20 to $2.30 \mathrm{~m}$ depth. Assoc. with Lauricocha II culture. Comment: date of carbonates fraction has not been corrected for isotopic fractionation.
GrN-5519. Lauricocha Cave L-2, Layer 28, $\quad 4650 \pm 130$ residue
2700 B.c.
$\delta C^{13}=-23.8 \%$ o

Sediments from 2.70 to $2.80 \mathrm{~m}$ depth. Assoc. with Lauricocha II.

GrN-5518. Lauricocha Cave L-2, Layer 31, residue

$5170 \pm 140$

3220 B.C.

$\delta C^{13}=-24.0 \%$

GrN-5589. Lauricocha Cave L-2, Layer 31, humic extract

$4660 \pm 90$

2710 B.C.

Sediments from 3.05 to $3.10 \mathrm{~m}$ depth. Assoc. with Lauricocha II, probably with its beginning. It is continuation of Layer P (Cardich, 1964, fig. 22), above Skeleton 11 (child). Skeleton 6 was lying on lowest 2 Layers $\mathrm{Q}$ and $\mathrm{R}$.

\section{GrN-5673. Lauricocha Cave L-2, Layer 32, residue}
GrN-5677. Lauricocha Cave L-2, Layer 32, humic extract

Sediments from below Layer $\mathrm{P}$ thought to correspond to (see samples of Layer 31, above).

General Comment: there is discrepancy between dates for Layers 31 and 32, and above mentioned date for Level $\mathrm{R}$ which is $20 \mathrm{~cm}$ deeper than Layer 31 , but possibility of disturbance in regularity of stratigraphy (hiatus or irregular occupation of shelter) cannot be ruled out without 
further investigation. Dates are younger than suggested in time sequence of Mayer-Oakes (1963). Dates for humic fractions do not seem significantly different for most layers.

\section{Cañón de Ancón series, Lima, Peru}

Prehistoric village near Ancón ( $11^{\circ} 44^{\prime} \mathrm{S}$ Lat, $77^{\circ} 8^{\prime} \mathrm{W}$ Long), dept. of Lima, in dry canyon $5 \mathrm{~km}$ E of Pacific Ocean, $38 \mathrm{~km} \mathrm{~N}$ of city of Lima, dept. of Lima, Peru. Coll. 1968 and subm. by F. Engel, Univ. Nac. Agraria, Lima, Peru.

\section{GrN-5546. Ancón 6707}

$$
\begin{aligned}
& 3655 \pm 45 \\
& 1705 \text { в.C. }
\end{aligned}
$$

Shells exposed on top of bleached and eroded refuse mound at Site 11B-VIII-153, Level 0. Purpose of sample was to correlate refuse heap with preceramic cultures in canyon. Comment: no correction for isotopic fractionation applied. Pretreated only with diluted HCl.

\section{GrN-5544. Ancón 6709}

Charred plant remains from cooking platform outside one of several stone houses at village 11B-VIII-160, Level 1. Refuse outside dwelling contains potatoes, other tubers and unidentified seeds and plant remains. Comment: as expected, date correlates with preceramic complex El Paraíso: $3570 \pm 150$ в.P. (I-1676, unpubl.) (Engel, 1966a, 1966b). Plant remains probably of same species as Chilca V. 2486 (below) .

Charcoal from hearth in trial trench in refuse mound covering aceramic village (Site 12B-VII-908, Level 1$)$ of reed huts $\left(12^{\circ} 28^{\prime} \mathrm{S}\right.$ Lat, $76^{\circ} 47^{\prime} \mathrm{W}$ Long) at base of Cerro Pucusana, in Cañón de Chilca (see series below) dept. of Lima, Peru. This is 1 of 5 settlements found in a row at coastal desert (Engel, 1966a). Coll. 1966 and subm. by F. Engel.

\section{Cañón de Chilea series, Lima, Peru}

Prehistoric villages on $\mathrm{N}$ bank of Quebrada de Chilca, near Chilca (ca. $12^{\circ} 35^{\prime} \mathrm{S}$ Lat, $76^{\circ} 40^{\prime} \mathrm{W}$ Long), in dry canyon $4 \mathrm{~km}$ from Pacific coast, $67 \mathrm{~km} \mathrm{~S}$ of city of Lima, dept. of Lima, Peru. Refuse mounds present over more than 2 hectares, described by Donnan (1964) and Engel (1966a). Coll. 1966 and 1967 by F. Engel and B. Ojeda, respectively; subm. by F. Engel.

\section{GrN-5547. Chilea, V. 1059}

$5130 \pm 110$ 3180 B.C.

$\delta C^{13}=-25.3 \%$

Fine charcoal from deep refuse mound at Site 12B-VII-50, Levels 3 and 4 buried under blown sand. Assoc. with unidentified plant remains. Probably pre-agricultural settlement. Expected to date 6000 B.P. or older. 
GrN-5520. Chilca, V. 2486

Charred plant remains, from hearth at reed huts village, Site 12BVII-2017, Level 1, thought to be pre-agricultural settlement.

General Comment: House 12 yielded piece of cane which dated UCLA664: $5370 \pm 120$ в.P. (Radiocarbon, 1964, v. 6, p. 335; Donnan, 1964).

\section{Yavi Chico series, Jujuy, Argentina}

\section{E. Argentina}

Site described by Boman (1908) near Bolivian border, at Yavi Chico $\left(22^{\circ} 7^{\prime} \mathrm{S}\right.$ Lat, $65^{\circ} 25^{\prime} 20^{\prime \prime} \mathrm{W}$ Long), $3200 \mathrm{~m}$ alt ca. $5 \mathrm{~km} \mathrm{~N}$ of Yavi and $17 \mathrm{~km} \mathrm{E}$ of La Quiaca, prov. of Jujuy, Argentina. In higher part of Terrace II of Yavi Chico river, ruins of large rectangular rooms of stone and adobe are found. Underground rooms seem to have served as silos (Krapovickas, 1965) and contain no burials. Thus this settlement differs from those of Humahuaca culture. Rock engravings in neighborhood reproduce patterns on pottery from silos (Krapovickas, 1961). Unidentified charred seeds also occur. Samples were expected to be later than A.D. 1100 and to represent the transition pre-Inca to Inca periods. Excavations by P. Krapovickas and collaborators since 1960. Coll. 1965 and subm. by P. Krapovickas, Tres Arroyos 518, Buenos Aires, Argentina.

\section{GrN-5464. Yavi Chico A}

Charred wood (YAV 05 XII-MRG 1) from one of rooms described above, found at 2.70 to $3.00 \mathrm{~m}$ depth in Layer XII under several alluvial deposits containing potsherds. Supposed to have belonged to roof of dwelling.

\section{GrN-5484. Yavi Chico BI}

$$
\begin{aligned}
& \mathbf{1 0 2 0} \pm \mathbf{3 0} \\
& \text { A.D. } 930 \\
& \delta C^{13}=-21.6 \%
\end{aligned}
$$

Charred wood (YAV 06 VI-MRG 1) from roof of building close to $\mathrm{A}$, in Layer VI, at $3 \mathrm{~m}$ depth, covered by several alluvial deposits containing potsherds.

\section{GrN-5458. Yavi Chico B2}

$$
\begin{array}{r}
490 \pm \mathbf{3 5} \\
\text { A.D. } 1460 \\
\delta C^{13}=-22.4 \%
\end{array}
$$

Charred straw (YAV 06 VI-MRC 2) from roof of same building as B1. Comment: historical date between A.D. 1400 and A.D. 1440, estimated from tree-ring calibration curve for $\mathrm{C}^{14}$.

General Comment: dates were expected to be closer to each other, especially B1 and B2 which seem to belong to same roof. Date of straw thatch should be preferred to that of wood which may have been old when roof was built. As site lies in desert, wood had to be brought from 
E mts.; re-use of older wood is conceivable. Collector considers B2 more acceptable on archaeologic grounds. Only comparable dates in Puna de Jujuy are from Pozuelo, A-244: $810 \pm 150$, and A-245: $820 \pm 150$ (Radiocarbon, 1962, v. 4, p. 247).

$\begin{array}{ll}\text { GrN-5190. } & \text { Falda del Cerro, Humahuaca, Jujuy, } \\ \text { Argentina } & 1210 \pm 30 \\ \text { A.D. } 740 & \end{array}$ $\delta C^{13}=-23.3 \%$

Charcoal from hearth in trench excavated at $2.20 \mathrm{~m}$ depth at Falda del Cerro (23 $10^{\prime} 30^{\prime \prime} \mathrm{S}$ Lat, 65 $25^{\circ} 05^{\prime \prime} \mathrm{W}$ Long), $2960 \mathrm{~m}$ alt, dept. of Humahuaca, prov. of Jujuy, Argentina. Sample assoc. with Black-on-Red Tilcara and Hornillos type ceramics (Bennett et al., 1948). Some fragments of Alfarcito Polychrome pottery were also found. Expected date ca. A.D. 1300-Middle period of Central NW Argentina culture. Coll. 1965 and subm. by E. M. Cigliano. Mus. de La Plata, Argentina. Comment: result suggests that Black-on-Red ceramic horizon is earlier in Humahuaca area than in region of Catamarca.

\section{GrN-5440. Quebrada de Juella, Jujuy, Argentina A.D. 1360 \\ $\delta C^{13}=-14.4 \%$}

$590 \pm 30$

Collagen from human bones ( $\mathrm{J}-\mathrm{CI} / 1 \mathrm{~B})$, from excavation in Quebrada de Juella (Jüella) $\left(23^{\circ} 30^{\prime} \mathrm{S}\right.$ Lat, $65^{\circ} 24^{\prime} \mathrm{W}$ Long), ca. $3000 \mathrm{~m}$ alt, Quebrada de Humahuaca, $10 \mathrm{~km} \mathrm{~N}$ of Tilcara, prov. of Jujuy, Argentina. Bare human bones with deformed skulls found $1.40 \mathrm{~m}$ below surface of settlement, in burial chamber $(\mathrm{CI} / \mathrm{B})$ separated from upper burials by layer of consolidated mud. Higher agricultural settlement was built on top of Quaternary alluvial fan forming plateau $40 \mathrm{~m}$ above valley on right bank of river. Stone and mud mortar dwellings were partially buried. One shell of species from $\mathrm{N}$ Chile was found at $1 \mathrm{~m}$ depth. Assoc. ceramics, of types Hornillos and Tilcara Black-on-Red, Angosto Chico Incised, and Poma Black-on-Red as described by Bennett et al. (1948), indicate Late period of Humahuaca culture described by Cigliano (19611964, 1967a) and by Pelissero (1967). Sample expected to date phases Humahuaca II or Belén II. Coll. 1966 and subm. by N. Pelissero, Mus. Arqueol. Pucará, Tilcara, Jujuy, Argentina. Comment: compare M-1639 (unpubl.): $630 \pm 120$ (Cigliano, 1966a) and IVIC-186: $1320 \pm 90$ (Radiocarbon, 1966, v. 8, p. 210) for same site. Last late seems too old for Late period. According to Cigliano (1967a), these 2 dated samples belong to same fragment of bow from Room 21. Pretreated with diluted HCl. Sample contained ca. $10 \%$ collagen. Date corrected for isotopic fractionation (see Introduction).

\section{GrN-5400a. Ciénaga Grande, Jujuy, Argentina}


GrN-5400b. Ciénaga Grande, Jujuy, Argentina

A.D. 1290

$\delta C^{13}=-15.6 \%$

Collagen from animal bones found in refuse mound at Ciénaga Grande (23 $43^{\prime} \mathrm{S}$ Lat, $65^{\circ} 30^{\prime} \mathrm{W}$ Long), $2750 \mathrm{~m}$ alt, dept. of Tumbaya, prov. of Jujuy, Argentina. Bones excavated at 1.40 to $1.50 \mathrm{~m}$ depth and assoc. with ceramics of Black-on-Red type, Late period. Site described by Salas (1945). Analyzed sample should date classical site of Quebrada de Humahuaca. Coll. 1964 and subm. by E. M. Cigliano. Comment: expected age was 400 to $500 \mathrm{yr}$. Date would indicate early phases of Late period. Sample contained $16 \%$ collagen combusted in 2 fractions: GrN-5400b volatile, and GrN-5400a non-volatile fraction. Both give same result.

\section{GrN-5147. Santa Rosa de Tastil, Salta, Argentina A.D. 1420}

$\mathbf{5 3 0} \pm \mathbf{3 0}$

$\delta C^{13}=-21.0 \%$

Charcoal from SE sector of excavation in Santa Rosa de Tastil $\left(24^{\circ}\right.$ $25^{\prime} \mathrm{S}$ Lat, $66^{\circ} \mathrm{W}$ Long), $2800 \mathrm{~m}$ alt, dept. of Rosario de Lerma, prov. of Salta, Argentina. Santa Rosa de Tastil, large prehistoric town (Boman, 1908) in Valleys of Toro and de Las Cuevas Rivers, is situated on top of plateau $200 \mathrm{~m}$ high with ca. 400 houses built with big blocks of worked stone. Every house has more than 1 room and most include burials. Potsherds of Middle and Late Ceramic periods have been found at $40 \mathrm{~cm}$ depth in refuse heap, assoc. with food remains, animal bones, pottery, metal objects, textiles, cultivated vegetables, maize, and Phaseolus sp. Lower stratum contained rattle-necklace made of Canna sp. seeds within Juglans sp. nuts. One of seeds was germinated under care of Sívori et al. (1968); see comments by Godwin (1968). Sample expected to date Black-on-Red pottery horizon of Late period in $W$ and influence of Puna cultures in Central NW Argentina (ca. A.D. 1350 to A.D. 1450). Coll. 1966 and subm. by E. M. Cigliano. Comment: derived from $\mathrm{C}^{14}$ correction curve (see Introduction), historical date is A.D. 1390 to A.D. 1420, in agreement with expectations of collector. End of human occupation of site is estimated to have occurred about mid-15th century on basis of this date. Sívori et al. (1968) erroneously quote sample to be bone.

\section{GrN-5399. Las Cuevas S. I, Salta, Argentina}

$1695 \pm 30$ A.D. 255

$\delta C^{13}=-15.4 \%$

Collagen from bones (Camelidae sp.) from 40 to $50 \mathrm{~cm}$ depth in refuse mound at Las Cuevas (24 $20^{\prime} \mathrm{S}$ Lat, 66 $16^{\circ} 5^{\prime} \mathrm{W}$ Long), $3100 \mathrm{~m}$ alt, dept. of Rosario de Lerma, prov. of Salta, Argentina. No dwellings have yet been found. Site at $14.5 \mathrm{~km} \mathrm{~W}$ of Santa Rosa de Tastil (see above). Same layer yielded fragment of pathologic mandible (Lama sp.) (T. Molleson, British Mus. Nat. Hist., written commun., 1968). Assoc. with Red-engraved potsherds fired in reducing atmosphere, related to San Pedro de Atacama culture of $\mathbf{N}$ Chile. Other finds were Condorhuasi Tricolor cylindrical vases which show influences of that culture in Puna. 
First site in area with sherds of unguiculate decoration, which suggests contacts with Lerma valleys. No Black-on-Red ceramics have been found. Date was expected to correspond to Early period of NW Argentina and N Chile, at least 1000 B.P. Coll. 1967 and subm. by E. M. Cigliano. Comment: compare dates for $\mathrm{N}$ Chilean San Pedro culture, Phase I: Sa-109: $1650 \pm 150$ (Radiocarbon, 1964, v. 6, p. 244), and Sa-226: 1700 \pm 150 (Radiocarbon, 1965, v. 7, p. 238). Sample contained ca. $16_{\%}^{\%}$ collagen. Date corrected for isotopic fractionation (see Introduction).

\section{La Candelaria series, Salta, Argentina}

Charcoal samples from 2 sites attributed to La Candelaria culture, described by Rydén (1936) and Willey (1946). Both sites located in dept. of La Candelaria, at ca. $500 \mathrm{~m}$ alt, prov. of Salta, Argentina. Samples subm. by A. Rex González for O. R. Heredia, Crámer 348, Buenos Aires.

\section{GrN-5415. El Quebrachal S. I}

$910 \pm 45$

\section{A.D. 1040}

$\delta C^{13}=-23.6 \%$

Charcoal from hearth found at 65 to $68 \mathrm{~cm}$ depth in excavation of Site I, Grid A, at El Quebrachal (26 $7^{\circ} \mathrm{S}$ Lat, $65^{\circ} 7^{\prime} \mathrm{W}$ Long) near $\mathrm{E}$ boundary of La Candelaria culture. Hearth was on floor of more primitive dwelling than those found in $\mathrm{W}$; assoc. with potsherds of undercorated pottery which, in other sites, occurs together with typical La Candelaria Gray- and Black-engraved ware. Was expected to date Earlier period. Coll. 1965 by O. Heredia and L. Federici.

\section{GrN-5416. El Algarrobal S. V}

$$
\begin{array}{r}
\mathbf{1 5 5 0} \pm \mathbf{3 5} \\
\text { A.D. } 400 \\
\delta C^{13}=-23.8 \%
\end{array}
$$

Charred wood from burial urn found 1.11 to $2.23 \mathrm{~m}$ deep at site $\mathrm{V}$, Grid F, NE corner at El Algarrobal (26 $6^{\circ} 6^{\prime} \mathrm{S}$ Lat, $65^{\circ} 2^{\prime} \mathrm{W}$ Long). Two human skeletons lay on top of $10 \mathrm{~cm}$ thick layer of charcoal from where sample was taken. Urn provisionally designated as Ceibal type (Heredia, 1968). Coll. Nov. 1965 by R. Carpe.

General Comment: 1st dates for area. Urn was thought to date earlier or later than La Candelaria culture. Although expected to be more probably later (Heredia, 1968), there is no conclusive archaeologic evidence to contradict result. El Quebrachal dates younger than expected but also considered acceptable.

\section{GrN-5414. Ongamira Alero Grande, Córdoba, Argentina}

$$
\begin{array}{r}
6510 \pm 100 \\
4560 \text { B.c. } \\
\delta C^{13}=-17.1 \% \circ
\end{array}
$$

Charcoal from oldest occupation level in SE of rock-shelter Alero Grande (or Deodoro Roca) in Ongamira Cave (ca. $30^{\circ} 45^{\prime} \mathrm{S}$ Lat, $64^{\circ} 28^{\prime}$ W Long), at ca. $1150 \mathrm{~m}$ alt, near locality of Ongamira, ca. $14 \mathrm{~km} \mathrm{NE}$ of Capilla del Monte, prov. of Córdoba, Argentina. Sample from level ca. $6 \mathrm{~m}$ deep, probably Horizon IV of description by Menghin and Gon- 
zález (1954). Level classified as protoarchaic stage by Krieger (1964). This shelter was initially excavated by the late $A$. Montes who coll. sample in 1958; subm. 1968 by A. Rex González, Dept. Anthropol., Harvard Univ., Cambridge, Massachusetts. Comment: date according to original expectation of submitter (Krieger, 1964). Submitter now advocates date of 2000 to 3000 B.c. (A. Rex González, written commun., 1968). Other Argentine preceramic dates are Intihuasi Y-228: $7970 \pm 100$ (Science, 1957 , v. 126, p. 915) and P-345: $8060 \pm 100$ (Radiocarbon, 1962, v. 4, p. 157) (A. Rex González, 1960, 1963).

\title{
GrN-5476. Calingasta, San Juan, Argentina
}

\author{
$915 \pm 55$ \\ A.D. 1035 \\ $\delta C^{13}=-24.4 \%$
}

Cloth from "mummy" (20200) found in Cave 2, in Calingasta (ca. $31^{\circ} 20^{\prime} \mathrm{S}$ Lat, $69^{\circ} 20^{\prime} \mathrm{W}$ Long), ca. $1400 \mathrm{~m}$ alt, on right bank of river of same name, prov. of San Juan, Argentina. Site excavated and described by Debenedetti (1917). Poncho cloth woven from wool of Lama sp. (M. D. Millán de Palavecino, in preparation). Finds suggest assoc. with agricultural and pottery-making culture named Calingasta, Phase II (A. Rex González, 1967). Ceramics of Calingasta culture described by Bennett et al. (1948). Coll. 1916 by S. Debenedetti and kept at Mus. Etnográfico, Buenos Aires. Subm. 1967 by A. Rex González. Comment: pretreated only with acid. Another portion of sample disintegrated completely in alkaline solution. Precipitate from solution gave GrN-5475: $710 \pm 60\left(\delta \mathrm{C}^{13}\right.$ $=-19.8 \%(c)$. Thus date $910 \pm 55$ в.P. must be considered minimum. Submitter expected date similar to UCLA-785C: $1550 \pm 60$ B.P. (Radiocarbon, 1967 , v. 9 , p. 485) but considers date acceptable and within time margin of Calingasta culture, Phase III.

\section{Gruta del Indio series, Mendoza, Argentina}

Several occupation horizons in rock shelter at Rincón del Atuel (ca. $34^{\circ} 50^{\prime} \mathrm{S}$ Lat, $68^{\circ} 30^{\prime} \mathrm{W}$ Long), $660 \mathrm{~m}$ alt, $28 \mathrm{~km} \mathrm{~S}$ of San Rafael, prov. of Mendoza, Argentina. Gruta del Indio is one of several caves formed in basaltic range Cerro Negro del Escorial (Semper and Lagiglia, 1969). Lowest level was occupied by extinct fauna and youngest is post-Columbian. Cultural horizons provisionally classified as Atuel I to IV. Upper horizon (Atuel I), not dated, corresponds to cave pictographs which seem to represent Spanish soldiers.

Pollen analyses of series of samples from Grid P-6 and T. van der Hammen show considerable differences between lower and upper parts of sec. Chenopodiaceae/Amaranthaceae-type pollen is present throughout sec., but is main element in upper sample (from $40 \mathrm{~cm}$ ) while Compositae dominate in other samples. Below $60 \mathrm{~cm}$ Nothofagus-Coniferae pollen was found in all samples, indicating existence of prehistoric forest in region. Mylodon sp. dung appears at $80 \mathrm{~cm}$ depth in this sec. and was also analyzed. It contained almost exclusively pollen of Chenopodiaceae/ Amaranthaceae-type; plant remains in pollen slides were principally spiral-vessels (van der Hammen, written commun., 1968). This is 1st 
dated pollen analysis of Central W Argentina. Coll. 1959 to 1961 by H. A. Lagiglia, J. V. Semper, and assoc.; subm. by H. A. Lagiglia, Mus. Hist. Nat., San Martín 127, San Rafael, Mendoza, Argentina.

GrN-5398. Gruta del Indio 5, acid

\section{GrN-5473. Gruta del Indio 5, unpretreated}

$\delta C^{13}=-26.2 \%$
Portion of 3037 beans (Phaseolus vulgaris, var. oblongus Alef, id. by M. G. Escalante, Univ. La Plata) contained in basket (Lagiglia, 1963). Excavated at rightsice of cave, Grid $V-6,30 \mathrm{~cm}$ below disturbed by intruders. Two as yet unidentified fruits or seeds were found in same basket. Considered as belonging to Atuel II. Comment: sample was suspected of contamination due to 2 sources: naphtalene in mus. and excrement of bats in shelter. As alkali pretreatment left too little material, it was necessary to perform only acid pretreatment ( $\mathrm{GrN}$ 5398) after leaving sample in oven for some hours to allow for sublimation of naphtalene. Unpretreated sample $(\mathrm{GrN}-5473)$ shows no significant difference in age. Thus it seems unlikely that dates could be affected by large errors.

\section{GrN-5397. Gruta del Indio 4}

$$
\begin{array}{r}
1910 \pm 60 \\
\text { A.D. } 40 \\
\delta C^{13}=-19.8 \%
\end{array}
$$

Leather and wool (Lama sp.) from funerary wrapping (Semper and Lagiglia, 1969), at 40 to $50 \mathrm{~cm}$ depth, left side of shelter, Grid B-6. Considered to belong to Atuel II. Burial 1 consisted of mummy of child with circular basket on its head. Matting, basketry, and leather bags were assoc. Zigzag pattern decoration on leather bag is thought to be related to rock paintings of nearby shelter and to Condorhuasi style of Argentine NW. Comment: pretreated only with acid.

GrN-5396. Gruta del Indio 3

$$
\begin{array}{r}
2065 \pm 40 \\
115 \text { B.C. } \\
\delta C^{13}=-10.2 \% \circ
\end{array}
$$

Ear of maize (MSR-3502), from 30 to $35 \mathrm{~cm}$ depth at left side of cave, Grid C-4. Considered to belong to Atuel II. Stratum was removed by intruders down to $30 \mathrm{~cm}$ depth. Several cobs and 2 ears of maize assoc. with remains of Cucurbita sp. This maize is Chapalote, primitive race known in Mexico (W. Galinat and P. C. Mangelsdorf, written commun., 1968). Comment: only acid pretreatment. Date corrected for isotopic fractionation (see Introduction).

\section{GrN-5395. Gruta del Indio 2}

$$
\begin{aligned}
& 3810 \pm 40 \\
& 1860 \text { B.C. } \\
& \delta C^{13}=-23.6 \%
\end{aligned}
$$

Wood (Geoffroea decorticans) from palisade protecting Burial 2. Partially mummified body was wrapped in woven Phragmites sp. form- 
ing basket. Other finds of same layer are matts of Cortaderia dioica flowers, and human bones. Sample found between 45 and $95 \mathrm{~cm}$ below floor of shelter, at left side, Grids E4 and E5. Considered as belonging to Atuel III.

\section{GrN-5394. Gruta del Indio 1}

$8045 \pm 55$ 6095 B.c.

$$
\delta C^{13}=-17.5 \%
$$

Wood charcoal from hearth above dung horizon (see below). Pieces of charcoal were found in cavity of hollow stone, together with 250 dermal ossicles of Mylodon Listai Ameg (Krag.), at $70 \mathrm{~cm}$ depth on right side of shelter, Grid RR-9. Considered to belong to Atuel IV; probably assoc. with piece of wolframite thought to be artifact (Lagiglia, 1962). Comment: other dates of extinct fauna in S South America assoc. with human occupation are Palli Aike, C-485: $8639 \pm 450$ (Libby, 1955, p. 134; Science, 1951, v. 113, p. 111-120) and Fell's Cave, W-915: 10,720 \pm 300 (Radiocarbon, 1961, v. 3, p. 96).

\section{GrN-5558. Gruta del Indio 6}

$$
\begin{array}{r}
10,950 \pm 60 \\
9040 \text { B.C. } \\
\delta C^{13}=-22.9 \% \circ
\end{array}
$$

Dung from deepest level of rock shelter, $1.10 \mathrm{~m}$ below surface, Grid RR-8. Coprolites id. as Mylodon sp. by comparison with remains from Patagonian sites investigated by Bird $(1946,1951)$. No definite proof of human remains found assoc. Comment: age correlates well with dates of Patagonian sites with same extinct fauna, C-484: 10,832 \pm 400 (Libby, 1955, p. 134; Science, 1951, v. 113, p. 111-120); Sa-49 from same site and layer as C-484 (Deevey et al. (eds.), 1967, p. 140-142): 10,200 \pm 400 (Radiocarbon, 1964, v. 6, p. 244).

General Comment: (Lagiglia and Lerman, 1968) 1st dated sequence of Central W Argentina shows several interesting facts such as contemporary existence of Mylodon in Mendoza and S Patagonia at ca. 8000 B.P. (Sample 1), and agricultural settlement with domestic animals at 2000 B.P. (Samples 3-5). Origin of ear of maize poses problem for existing archaeologic schemes.

\section{GrN-5506. Cerro Chico, Entre Ríos, Argentina}

$$
\begin{aligned}
& \mathbf{8 9 5} \pm \mathbf{3 5} \\
& \text { A.D. } 1055 \\
& \delta C^{13}=-3.7 \%
\end{aligned}
$$

Shells (Felipponea iheringi as id. by Castellanos and Birabén, Mus. La Plata) from $70 \mathrm{~cm}$ depth in excavation of refuse mound on bank of Uruguay R., at Cerro Chico (ca. $31^{\circ} 20^{\prime} \mathrm{S}$ Lat, $58^{\circ} 0^{\prime} \mathrm{W}$ Long), Salto Grande, near Concordia, dept. of Federación, prov. of Entre Ríos, Argentina. Species no longer prevalent in area, but found hundreds of $\mathrm{km}$ to $\mathrm{N}$, in Río Grande do Sul, Brazil. Mound is on terrace 5 to $7 \mathrm{~m}$ higher than present level of river, covered by 30 to $40 \mathrm{~cm}$ of humic soil. Archaeologic stratum extends from 70 to $80 \mathrm{~cm}$ depth. Assoc. finds were undecorted ceramics pre-Guaraní, 2 sherds of incised ceramics type Salto 
Grande-engraved, as described by Serrano (1955) and a few stone flakes. Site and finds are described by Cigliano (1967b, 1968). Coll. 1967 and subm. by E. M. Cigliano. Comment: 1st dated sample from Argentine Mesopotamia. Pretreated with diluted HCl. No correction for isotopic fractionation.

$405 \pm 35$

GrN-5146. El Arbolito, Martín García, Argentina A.D. 1545

$\delta C^{13}=-24.4^{\prime} / \%$

Charcoal from Guaraní settlement, assoc. with fragments of Guaraní pottery. Found in excavated hearth, at 50 to $60 \mathrm{~cm}$ depth, in Isla Martín García (34 $10^{\prime} \mathrm{S}$ Lat, $58^{\circ} 15^{\prime} \mathrm{W}$ Long), island in Río de La Plata, near mouth of Uruguay R., Argentina. Sample should date culture at this $\mathbf{S}$ locality. Coll. and subm. by E. M. Cigliano. Comment: date proves that Guaraní people settled as late as expected (Cigliano, 1968). Historical date estimated from $\mathrm{C}^{14}$ correction curve (see Introduction) is between A.D. 1440 and A.D. 1480 .

\section{$2990 \pm 40$ \\ GrN-5189. Palo Blanco 6-13, Buenos Aires, Argentina 1040 B.c. \\ $\delta C^{13}=-2.2 \%$}

Shells, Erodona mactroides (Daud.), from excavation at La Florida,

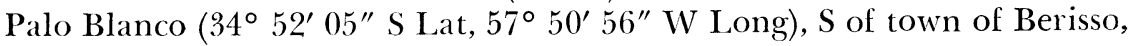
ca. $1 \mathrm{~km}$ from Río de La Plata, dept. of Berisso, prov. of Buenos Aires, Argentina. Excavated in geologic formation called Querandinense. Sample, from Trench 13, Layer 6, at $1.20 \mathrm{~m}$ depth (Cigliano, 1963, 1966b), assoc. with sherds of primitive, undecorated ceramics of style not yet known. Several dates already known for this formation, IVIC-188: 4760 \pm 120 (Radiocarbon, 1966 , v. 8, p. 211), IVIC-268: $3990 \pm 70$, and IVIC-269: $4520 \pm 70$ (Radiocarbon, 1967, v. 9, p. 242). First is from same site and other 2 are from $1 \mathrm{~km} \mathrm{~S}$ of Palo Blanco belonging to same formation. Another date from the formation is Palo Blanco S. II (IVIC266, unpubl.): $3820 \pm 80$ в.P. Coll. 1964 and subm. by E. M. Cigliano. Shells id. by Z. A. de Castellanos, Mus. La Plata, Argentina. Comment: date considered acceptable from geologic and archaeologic points of view (Cigliano, 1968) (compare Atlantic Shoreline series, this list). Other early ceramic sites in Central and South America are Monagrillo, Panamá, Y-585: $4090 \pm 70$ (Radiocarbon, 1959, v. 1, p. 166); Rancho Peludo, Venezuela, Y-578: $4630 \pm 150$ (Radiocarbon, 1963, v. 5, p. 335); Puerto Hormiga, Colombia (Reichel-Dolmatoff, 1965): $4875 \pm 170$ (I-445, unpubl.) and SI-151, $4820 \pm 1000$; SI-152, $4970 \pm 70$, SI-153, $5040 \pm 70$ (Radiocarbon, 1966, v. 8, p. 417) as well as 2 phases from Ecuador, Valdivia ca. 5000 B.P. and Machalilla ca. 4000 B.P., on basis of 23 dates (Meggers et al., 1965). Pretreated with diluted HCl. Date not corrected for isotopic fractionation. 
III. GEOCHEMICAL SAMPLES

\section{Atmospheric Carbon Dioxide}

\section{Bariloche series, Río Negro, Argentina}

Ground level atmospheric $\mathrm{CO}_{2}$ from Centro Atómico Bariloche $\left(41^{\circ}\right.$ $8^{\prime} \mathrm{S}$ Lat, $71^{\circ} 25^{\prime} \mathrm{W}$ Long), at $800 \mathrm{~m}$ alt in N Patagonian Andes, $10 \mathrm{~km}$ $\mathrm{W}$ of Bariloche, prov. of Río Negro, Argentina. $\mathrm{CO}_{2}$ was absorbed in $\mathrm{NaOH}$ solution and either directly submitted (BAR-1 to -4) or firstly precipitated with $\mathrm{Ba}(\mathrm{OH})_{2}(\mathrm{BAR}-5$ to -44$)$. Coll. and subm. by E. Bonacalza, Centro Atómico Bariloche, Bariloche, Argentina.

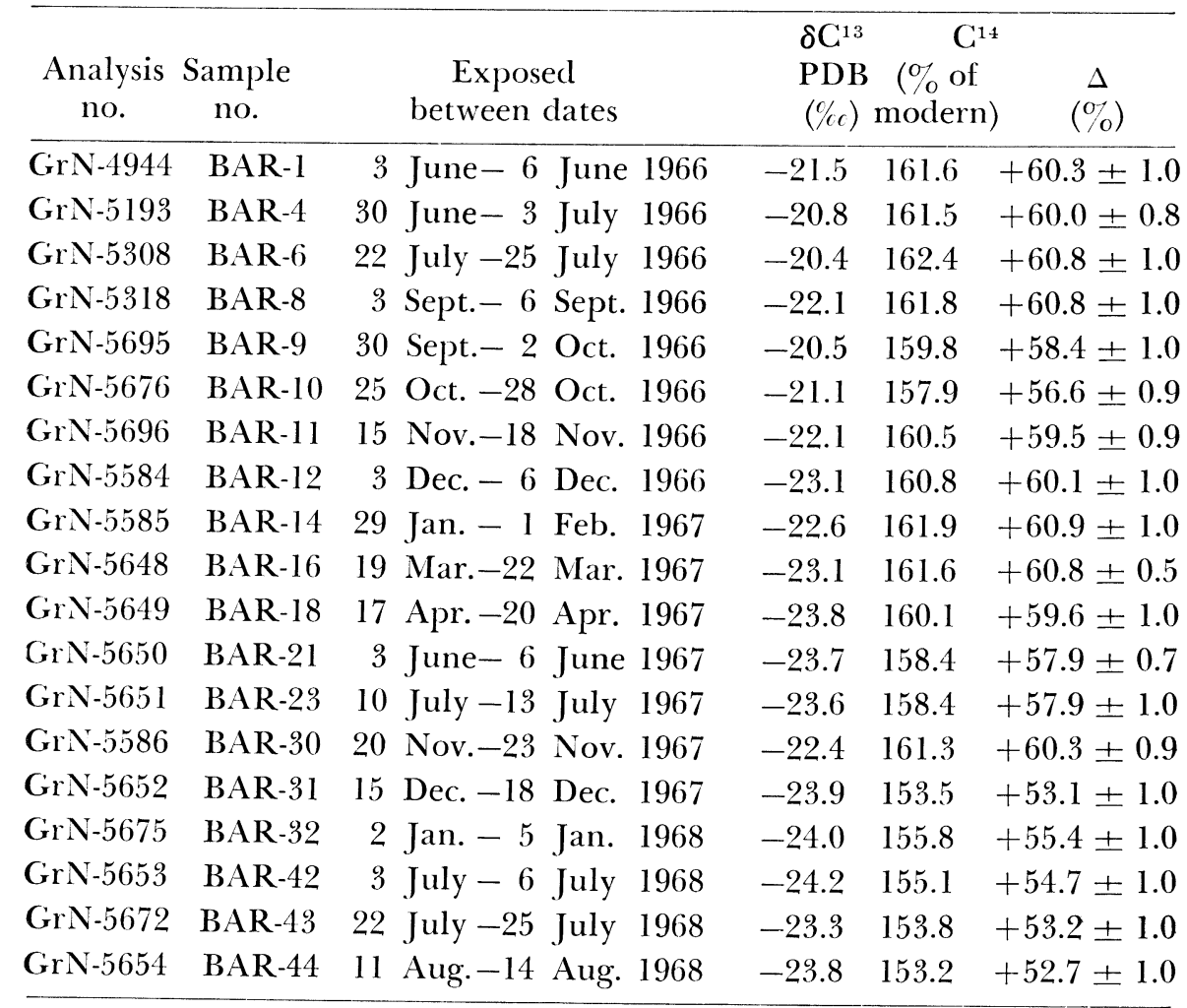

General Comment: other publ. S Hemisphere $\mathrm{CO}_{2}$ analyses are from: New Zealand (Rafter, 1965) at about same lat as Bariloche; São Carlos, São Paulo (22 S Lat), Brazil (Radiocarbon, 1968, v. 10, p. 414); Pretoria (25 43' S Lat), South Africa (Vogel, cited by Münnich and Roether, 1967); and Madagascar (21 $27^{\prime}$ S Lat) (Nydal, 1968). There seems to be no increase due to nuclear tests started on 5 June 1966 in Mururoa atoll $\left(22^{\circ} \mathrm{S}\right.$ Lat), Pacific Ocean. Patagonian values coincide with measurements in $\mathrm{N}$ Hemisphere at Abisko, Sweden $\left(68^{\circ} \mathrm{N}\right.$ Lat) about end 1967 (Olsson, 1968; Radiocarbon, 1970, v. 12, in press). 


\title{
REFERENCES
}

Date lists:

Arizona III
Chicago I
Copenhagen IV
Groningen IV
Groningen V
IVIC II
IVIC III
La Jolla V
Lamont II
Lamont VII
Pennsylvania V
Saclay I
Saclay II
Smithsonian III
UCLA III
UCLA VI
UCLA VIII
USGS V
USGS VI
Yale III
Yale IV
Yale VIII
Yale IX

\author{
Damon and Long, 1962 \\ Arnold and Libby, 1951 \\ Tauber, 1960 \\ Vogel and Waterbolk, 1963 \\ Vogel and Waterbolk, 1964 \\ Tamers, 1966 \\ Tamers, 1967 \\ Hubbs and Bien, 1967 \\ Kulp, Tryon, Eckelman, and Snell, 1952 \\ Olson and Broecker, 1961 \\ Ralph and Stuckenrath, 1962 \\ Delibrias, Guillier, and Labeyrie, 1964 \\ Delibrias, Guillier, and Labeyrie, 1965 \\ Long and Mielke, 1966 \\ Fergusson and Libby, 1964 \\ Berger and Libby, 1967 \\ Berger and Libby, 1968 \\ Rubin and Alexander, 1960 \\ Rubin and Berthold, 1961 \\ Barendsen, Deevey, and Gralenski, 1957 \\ Deevey, Gralenski, and Hoffren, 1959 \\ Stuiver, Deevey, and Rouse, 1963 \\ Stuiver, 1969
}

Angulo Valdés, Carlos, 1963, Cultural development in Colombia, in: Aboriginal cultural development in Latin America; an interpretative review, Meggers, B. J. and Evans, Clifford, (eds.): Smithsonian Misc. Coll., v. 146, no. 1, p. 55-66.

Arnold, J. R. and Libby, W. F., 1951, Radiocarbon dates I: Science, v. 113, p. 111-120. Auer, Väinö, 1963, Lateglacial and postglacial shoreline displacements in South America as established by tephrachronology, compared with displacements of the Baltic shorelines: Fennia, v. 89, no. 1, p. 51-55.

Barendsen, G. W., Deevey, E. S., and Gralenski, L. J., 1957, Yale natural radiocarbon measurements III: Science, v. 126, p. 908-919.

Baudez, C. F., 1963, Cultural development in Lower Central America, in: Aboriginal cultural development in Latin America; an interpretative review, Meggers, B. J. and Evans, Clifford, (eds.): Smithsonian Misc. Coll., v. 146, no. 1, p. 45-54.

Bennett, W. C., Bleiler, E. F., and Sommer, F. H., 1948, Northwest Argentine archeology: Yale Univ. Publ. Anthropol., no. 38.

Berger, Rainer and Libby, W. F., 1967, UCLA radiocarbon dates VI: Radiocarbon, v. 9 , p. $477-504$.

1968, UCLA radiocarbon dates VIII: Radiocarbon, v. 10, p. 402-416.

Bird, Junius, 1946, The archaeology of Patagonia, in: Handb. S. Am. Indians, Steward, J. H. (ed.): Bur. Am. Ethnol. Bull., no. 143, v. 1, p. 17-24.

1951, South American radiocarbon dates, in: Radiocarbon dating, Johnson, F. (ed.): Mem. Soc. Am. Archaeol., no. 8, p. 37-49.

Boman, Eric, 1908, Antiquités de la région Andine de la Republique Argentine et du désert d'Atacama; 2 v., in: Mission Sci. G. de Créqui Montfort et E. Sénéchal de la Grange: Paris, Imprimerie Natl.

Brinkman, R. and Pons, L. J., 1968, Pedo-geomorphological classification and map of the Holocene sediments in the coastal plain of the three Guianas: Soil Survey Papers, no. 4, p. $1-40$.

Cardich, Augusto, 1964, Lauricocha; fundamentos para una prehistoria de los Andes Centrales: Studia Praehist., v. 3, p. 1-162 (German abs. by O. F. A. Menghin, p. 149-155).

Cigliano, E. M., 1961-1964, Práctica funeraria en los distintos entierros del yacimiento arqueológico de Juella (Prov. de Jujuy): Univ. Nac. Córdoba, Rev. Inst. Antropol., v. $2-3$, p. $263-272$.

1963, Arquelogía del NE de la provincia de Buenos Aires: Prov. Bs. Aires, Com. Inv. Cient., Anales, v. 4, p. 471-511.

1966a, Contribución a los fechados radiocarbónicos argentinos (I): Mus. La

Plata, Sec. Antropol., Rev., v. 6 (Nueva Ser.), p. 1-16. 
1966b, La cerámica temprana en América del Sur; el yacimiento de Palo Blanco (Partido de Berisso, Prov. de Buenos Aires, Argentina): Ampurias, v. 28, p. $163-170$.

1967a, Investigaciones antropológicas en el yacimiento de Jüella (Dep. de Tilcara, Provincia de Jujuy): Mus. La Plata, Sec. Antropol., Rev., v. 6 (Nueva Ser.), p. 123-249.

1967b, Nota preliminar sobre los hallazgos prehistóricos en la zona de Salto Grande (Entre Ríos): Prov. Bs. Aires, Com. Inv. Cient., Notas, v. 5, no. 3, p. $1-20$.

— 1968, Investigaciones arqueológicas en el río Uruguay medio y costa NE de la provincia de Buenos Aires, in: Arqueol. Area do Prata, São Leopoldo-1968: Porto Alegre, Brazil.

Damon, P. E. and Long, Austin, 1962, Arizona radiocarbon dates III: Radiocarbon, v. 4 , p. 204-238.

Debenedetti, Salvador, 1917, Investigaciones arqueológicas en los valles preandinos de la provincia de San Juan: Fac. Filosof. Letras, Pub. Sec. Antropol., no. 15, p. 4-185.

Deevey, E. S., Flint, R. F., and Rouse, Irving, (eds.), 1967: Radiocarbon measurements; comprehensive index, 1950-1965: Yale Univ., New Haven.

Deevey, E. S., Gralenski, L. J., and Hoffren, Väinö, 1959, Yale natural radiocarbon measurements IV: Am. Jour. Sci. Radiocarbon Suppl., v. 1, p. 144-172.

Delibrias, G., Guillier, M. T., and Labeyrie, J., 1964, Saclay natural radiocarbon measurements I: Radiocarbon, v. 6, p. 233-250. p. $236-244$.

Donnan, C. B., 1964, An early house from Chilca, Peru: Am. Antiquity, v. 30, p. 137-144.

Duque Gómez, Luis, 1963, Reseña arqueológica de San Agustín: Inst. Colombiano Antropol., Bogotá.

1964-1966, Exploraciones arqueológicas en San Agustín: Rev. Colombiana Antropol., Supl. no. 1, Inst. Colombiano Antropol., Bogotá.

Emery, K. O. and Garrison, L. E., 1967, Sea levels 7,000 to 20,000 years ago: Science, v. 157, p. $684-687$.

Engel, Frédéric, 1966a, Geografía humana prehistórica y agricultura pre-colombina de la Quebrada de Chilca, I, informe preliminar: Dept. Pub. Univ. Agraria, Lima. 1966b, Le complexe précéramique d'el Paraiso (Perou): Jour. Soc. Americanistes, v. 55-1, p. 43-96.

Fergusson, G. J. and Libby, W. F., 1964, UCLA radiocarbon dates III: Radiocarbon, v. 6, p. $318-339$.

Feriz, Hans, 1959a, Zwischen Peru und Mexico: Meded. Koninklijk Inst. Tropen, v. 134, Anthropol. no. 63, Amsterdam.

1959b, Zeugnisse einer unbekannten vorkolumbischen Kultur in Panama: Umschau Wiss. Tech., v. 59, p. 728-732.

- 1961, Bericht über Grabfunde am Isthmus von Panama in den Jahren 1956 und 1958, in: Internat. Kong. Vor- u. Frühgeschichte, 5th, Hamburg-1958: Berlin, Verlag Gebr. Mann, p. 260-266.

Fray, C., Ewing, M., Richards, H. G., and Craig, J. R., 1963, Pleistocene sedimentation and fauna of the Argentine shelf: [U.S.] Natl. Acad. Sci. Proc., v. 115, p. $113-152$.

Frenguelli, Joaquín. 1950, Rasgos generales de la morfología y la geología de la provincia de Buenos Aires: LEMIT, Ser. 2, no. 33, Lab. Ensayo Materiales Inv. Tecnol., M.O.P., La Plata.

Geijskes, D. C., 1960-1961, Archeologische vondsten van de zandritsen bij de Commetewanakreek (District Commewijne) in Suriname: Rijksdienst Oudheidkundig Bodemonderzoek, Berichten, v. 10-11, p. 95-124.

Godwin, H., 1968, Evidence for longevity of seeds: Nature, v. 220, p. 708-709.

González, A. Rex, 1960, La estratigrafía de la gruta de Intihuasi (Prov. de San Luis, R. A.) y sus relaciones con otros sitios precerámicos de Sudamérica: Univ. Nac. Córdoba, Rev. Inst. Antropol., v. 1, p. 1-302.

1963, Cultural development in northwestern Argentina, in: Aboriginal cultural development in Latin America; an interpretative review, Meggers, B. J. and Evans, Clifford, (eds.): Smithsonian Misc. Coll., v. 146, no. 1, p. 103-117.

del NO 1967, Arqueología de San Juan, in: Una excepcional pieza de mosaico del NO argentino: ETNIA, Rev. Mus. Etnogr. Municipal Olavarría, no. 6, art. 30 , p. $16-25$. 
González, Enrique, van der Hammen, T., and Flint, R. F., 1965, Late Quaternary glacial and vegetational sequence in Valle de Lagunillas, Sierra Nevada del Cocuy, Colombia: Leidse Geol. Meded., v. 32, p. 157-182.

Haberland, Wolfgang, 1962, The Scarified Ware and the early cultures of Chiriqui (Panama), in: Internat. Am. Kong., 34th, Wien-1960, Akten, p. 381-389: HornWien (Austria), Verlag F. Berger.

van der Hammen, T.. 1961, The Quaternary climatic changes of northern South America: New York Acad. Sci., Ânnals, v. 95, p. 676-683.

1962, Palinología de la región de "Laguna de los Bobos"; historia de su clima, vegetación y agricultura durante los últimos 5000 años: Acad. Colombiana Cienc. Exactas Fís. Nat., Rev., v. I1, p. 359-361.

1963, A palynological study on the Quaternary of British Guiana: Leidse Geol. Meded., v. 29, p. 125-180.

1965, The age of the Mondonedo Formation and the Mastodon fauna of Mosquera (Sabana de Bogotá): Geol. Mijnb., v. 44, p. 384-390.

1966, The Pliocene and Quaternary of the Sabana de Bogotá (The Tilatáand Sabana Formations): Geol. Mijnb., v. 45, p. 102-109.

van der Hammen, T. and Correal, G., 1967. Internal report on the excavations of El Abra site: Ms., Hugo de Vries Lab., Sarphatistr. 221, Amsterdam.

van der Hammen, T. and González, Enrique, 1960, Upper Pleistocene and Holocene climate and vegetation of the "Sabana de Bogotá" (Colombia, South America): Leidse Geol. Meded., v. 25, 261-315.

1965a, A pollen diagram from "Laguna de La Herrera" (Sabana de Bogotá): Leidse Geol. Meded. v. 32, p. 183-191.

1965b, A Late-Glacial and Holocene pollen diagram from Ciénaga del Visitador (Dept. Bovacá, Colombia): Leidse Geol. Meded, v. 32, p. 193-201.

van der Hammen, T. and Parada, A., 1958, Investigación de algunos importantes yacimientos de diatomita, caolín y arcillas de la sabana de Bogotá: Univ. Industrial Santander, Bol. Geol., v. 2, p. 5-25.

van der Hammen, T. and Vogel, J. C., 1966, The Susacá-Interstadial and the subdivision of the Late-Glacial: Geol. Mijnb., v. 45, p. 33-35.

Haynes, C. V., Jr., 1967, Carbon-14 dates and early man in the New World, in: Pleistocene extinctions; the search for a cause, Martin, P. S. and Wright, H. E., Jr. (eds.): Yale Univ. Press, New Haven, p. 267-286.

Heredia, O. R., 1968, Arqueología de la sub-área de las Selvas Occidentales: Cong. Internac. Am. 37th, Mar del Plata-1966, Actas, v. 2, Buenos Aires.

Hubbs, C. L. and Bien, G. S., 1967, La Jolla natural radiocarbon measurements V: Radiocarbon, v. 9, p. 261-294.

Hurt, W. R., 1968, A survey of non-ceramic sites in Colombia: Internat. Am. Kong., 38th, Stutgart-München-1968.

Jennings, J. D. and Norbeck, Edward (eds.), 1964, Prehistoric man in the New World: Chicago, Univ. Chicago Press.

Krapovickas, Pedro, 1961, Noticia sobre el arte rupestre de Yavi, provincia de Jujuy, República Argentina: Univ. Nac. Cuyo, Anales Arqueol. Etnol., v. 16, p. 135-167. 1965, La cultura de Yavi, una nueva entidad cultural puneña: ETNIA, Rev. Mus. Etnogr. Municipal Olavarría, no. 2, art. 12, p. 9-10.

Krieger, A. D., 1964, Farly man in the New World, in: Prehistoric man in the New World, Jennings, J. D., and Norbeck, Edward (eds.): Univ. Chicago Press, p. 23-81.

Kulp, J. L., Tryon, L. E., Eckelman, W. R., and Snell, W. A., 1952, Lamont natural radiocarbon measurements II: Science, v. 116, p. 409-414.

Ladd, J., 1964, Review of Panamanian archaeology, in: Archaeological investigations in the Parita and Santa María zones of Panama: Smithsonian Inst., Bur. Am. Ethnol., Bull., no. 193, p. 10-23.

Lagiglia, H. A., 1962, Instrumento cortante de wolframita nuevo para la arqueología de Mendoza: Cienc. Inv., v. 18, p. 131-133.

1963, Presencia del "Phaseolus vulgaris, var. oblongus Alef" en las excavaciones arqueológicas del Rincón del Atuel, Depto. de San Rafael (Mendoza), Argentina: Univ. Católica Chile, Rev., v. 48, p. 235-242.

Lagiglia, H. A. and Lerman, J. C., 1968, Chronology of western Argentina; Gruta del Indio, Mendoza: Internat. Am. Kong., 38th, Stuttgart-München-1968.

Lanning, E. P. and Patterson, T. C., 1967, Early man in South America: Sci. Am., v. 217 , no. 5 , p. $44-50$.

Libby, W. F., 1955, Radiocarbon dating, 2nd. ed.: Chicago, Univ. Chicago Press.

Linares de Sapir, Olga, 1966, La cronología arqueológica del Golfo de Chiriquí, Panamá: Cong. Internac. Am. 36th, Sevilla-1964, Actas, v. 1, p. 405-414. 
1968a, Ceramic phases for Chiriquí, Panama, and their relationship to neighboring sequences: Am. Antiquity, v. 33 , p. 216-225.

1968b, Chronological summary and comparison with other areas, in: Cultural chronology of the gulf of Chiriquí, Panama: Smithsonian Contr. Anthropol., v. 8 , p. $83-91$

Long, Austin and Mielke, J. E., 1966, Smithsonian Institution radiocarbon measurements III: Racliocarbon, v. 8, p. 413-422.

Lothrop, S. K., 1959, A re-appraisal of Isthmian archaeology, in: Am. Miszellen: Mitt. Hamburg Mus. Völkerkunde, v. 25, p. 87-91.

1960, $\mathrm{C}^{14}$ dates for Venado Beach, Canal Zone: Panama Archaeol., v. 3, p. 96. 1966. Archaeology of Lower Central America, in: Handb. Middle Am. Indians, v. 4, p. 180-208. Austin, Univ. Texas Press.

Mayer-Oakes, W. J., 1963, Early man in the Andes: Sci. Am., v. 208, no. 5, p. 116-128,

Meggers, B. J. and Evans, Clifford (eds.), 1963, Aboriginal cultural development in Latin America; an interpretative review: Smithsonian Misc. Coll., v. 146, no. 1.

Meggers, B. J., Evans, Clifford, and Estrada, Emilio, 1965, Early Formative period of coastal Ecuador; the Valdivia and Machalilla phases: Smithsonian Contr. Anthropol., v. 1.

Menghin, O. and González, $\Lambda$. Rex, 1954, Excavaciones arqueológicas en el yacimiento de Ongamira, Córdoba (Rep. Arg.): Fac. Cienc. Nat. Mus., Notas Sec. Antropol., v. 17, p. $213-274$

Montané, Julio, 1968, Paleo-Indian remains from Laguna de Tagua Tagua, Central Chile: Science, v. 161, p. 1137-1138.

Mostny, Grete, 1968, Estado actual de la arquelogía Chilena: Internat. Am. Kong., 38th, Stuttgart-München-1968.

Münnich, K. O., 1961, Fehlermöglichkeiten bei der C ${ }^{14}$-Analyse, in: Internat. Kong. Vor- u. Frühgeschichte, 5th, Hamburg-1958: Berlin, Verlag Gebr. Mann, p. 582-588.

Münnich, K. O. and Roether, W., 1967, Transfer of bomb $C^{14}$ and $T$ from the atmosphere to the ocean, in: Radioactive dating and methods of low level counting: Proc. Internat. Atomic Energy Agency, p. 94, Vienna.

Münnich, K. O. and Vogel, J. C., 1958, Durch Atomexplosionen erzeugter Radiokohlenstoff in der Atmosphäre: Naturwiss., v. 45, p. 327-329.

Nydal, Reidar, 1968, Further investigation on the transfer of radiocarbon in nature: Jour. Geophys. Research, v. 73, p. 3617-3635.

Olson, E. A. and Broecker, W. S., 1961, Lamont natural radiocarbon measurements VII: Radiocarbon, v. 3, p. 141-175.

Olsson, I. U., 1968, Modern aspects of radiocarbon datings: Earth-Sci. Rev., v. 4, p. $203-218$.

Patterson, T. C., 1965, Ceramic sequences at Tierradentro and San Agustín, Colombia: Am. Antiquity, v. 31, p. $66-73$

Pedersen, Asbjorn, 1966, Metalurgia indígena prehispánica americana, in: Cong. Hist. Catamarca, 1st, Catamarca-1958, v. 3, p. 39-50.

Pelissero, Norberto, 1967, Arqueología de la Quebrada de Juella, su integración en la cultura Humahuaca: Ms., Mus. Etnogr., Moreno 350, Buenos Aires.

Pérez de Barradas, José, 1943, Arqueología agustiniana; excavaciones arqueológicas realizadas de marzo a diciembre de 1937: Bogotá, Imprenta Nac.

Preuss, K. Th., 1929, Monumentale vorgeschichtliche Kunst; Ausgrabungen im Quellgebiet des Magdalena, in: Kolumbien und ihre Ausstrahlungen in Amerika: Goettingen.

Raasveldt, H. C., 1957, Las glaciaciones de la Sierra Nevada de Santa Marta, Asoc. Colombiana Cienc., Rev., v. 9, p. 469-48I.

Rafter, T. A., 1965, Carbon-14 variations in nature, part 2; increase in $\mathrm{C}^{14}$ activity $^{-}$in the atmosphere of the Southern Hemisphere from the testing of nuclear weapons: New Zealand Jour. Sci., v. 8, p. 472-493.

Ralph, E. K. and Stuckenrath, Robert, Jr., 1962, University of Pennsylvania radiocarbon dates V: Radiocarbon, v. 4, p. 144-159.

Reichel-Dolmatoff, Gerardo, 1965, Excavaciones arqueológicas en Puerto Hormiga (Departamento de Bolivar): Antropología, no. 2, p. 1-60.

Richards, H. G. and Broecker, Wallace, 1963, Emerged Holocene South American shorelines: Science, v. 141, p. 1044-1045.

Robledo, Emilio, 1955, in: Univ. Antioquia, Bol. Inst. Antropol., v. 1, p. 215-235.

Roeleveld, W., 1969, Pollenanalyses of two profiles in the young coastal plain of Surinam: Gicol. Mijn., v. 48 , in press. 
Rubin, Meyer and Alexander, Corrinne, 1960, U. S. Geological Survey radiocarbon dates V: Am. Jour. Sci. Radiocarbon Suppl., v. 2, p. 129-185.

Rubin, Meyer and Berthold, S. M., 1961, U. S. Geological Survey radiocarbon dates VI: Radiocarbon, v. 3, p. 86-98.

Rydén, Stig, 1936, Archaeological researches in the department of La Candelaria (Prov. Salta, Argentina): Ethnol. Studies, v. 3, p. 5-329.

Salas, M. A., 1945, El antigal de Ciénaga Grande (Quebrada de Purmamarca, Prov. de Jujuy): Mus. Etnogr., Pub. Ser. A, v. 5, p. 1-268.

Semper, J. V. and Lagiglia, H. A., 1969, Excavaciones arqueológicas en el Rincón del Atuel (Gruta del Indio), nota preliminar: Mus. Hist. Nat. San Rafael (Mendoza), Rev., in press.

Serrano, Antonio, 1955, Los pueblos y culturas indígenas del Litoral: Santa Fe, Argentina, Ed. Castellvi.

Shepard, F. P., 1963, Thirty-five thousand years of sea level, in: Essays in marine geology in honor of K. O. Emery, p. 1-10, Los Angeles, Univ. S Calif. Press.

1964 , Sea level changes in the past 6000 years-possible archeological significance: Science, v. 143, p. 574-576.

Silva Celis, Eliécer, 1945, Contribución al conocimiento de la cultura Lache: Bol. Arqueol., v. 1, no. 5, Bogotá. Arqueol., 1968, Arqueología y prehistoria de Colombia: Tunja, Prensas Univ. Pedagógica Tecnol. Colombia.

Sívori, E., Nakayama, F., and Cigliano, E. M., 1968, Germination of achira seed (Canna sp.) approximately 550 years old: Nature, v. 219, p. 1269-1270.

Stuiver, Minze, 1969, Yale natural radiocarbon measurements IX: Radiocarbon, v. 11, p. $545-648$.

Stuiver, Minze, Deevey, E. S., Jr., and Rouse, Irving, 1963, Yale natural radiocarbon measurements VIII: Radiocarbon, v. 5, p. 312-341.

Stuiver, Minze and Suess, H. E., 1966, On the relationship between radiocarbon dates and true sample ages: Radiocarbon, v. 8, p. 534-540.

Tamers, M. A., 1966, Instituto Venezolano de Investigaciones Científicas natural radiocarbon measurements II: Radiocarbon, v. 8, p. 204-212.

1967, Instituto Venezolano de Investigaciones Científicas natural radiocarbon measurements III: Radiocarbon, v. 9, p. 237-245.

Tauber, Henrik, 1960, Copenhagen radiocarbon dates IV: Am. Jour. Sci. Radiocarbon Suppl., v. 2, p. 12-25.

Teruggi, M. E. and Cetrángolo, Z. Ch. de, 1964, Estudio sedimentológico de los depósitos de la caverna L-2 de Lauricocha: Studia Praehist., v. 3, p. 163-171.

Vogel, J. C. and Waterbolk, H. T., 1963, Groningen radiocarbon dates IV: Radiocarbon, v. 5, p. 163-202.

1964, Groningen radiocarbon dates V: Radiocarbon, v. 6, p. 349-369.

Wijmstra, T. A., 1967, A pollen diagram from the Upper Holocene of the Lower Magdalena Valley: Leidse Geol. Meded., v. 39, p. 261-267.

Wijmstra, T. A. and van der Hammen, T., 1966, Palynological data on the history of tropical savannas in northern South America: Leidse Geol. Meded., v. 38, p. 71-90.

Willey, G. R., 1946, The culture of La Candelaria, in: Hand. S. Am. Indians, Steward, J. H. (ed.): Bur. Am. Ethnol. Bull., no. 143, v. 2, p. 661-672. 1966, An introduction to American archaeology, v. 1, North and Middle America: Englewood Cliffs (N.J.), Prentice-Hall. 